\title{
SP6616 as a new Kv2.1 channel inhibitor efficiently promotes $\beta$-cell survival involving both PKC/Erk1/2 and CaM/PI3K/Akt signaling pathways
}

\author{
TT Zhou ${ }^{1,2,4}$, LL Quan ${ }^{3,4}$, LP Chen ${ }^{1,2}$, T Du ${ }^{1,2}$, KX Sun ${ }^{1}$, JC Zhang ${ }^{3}$, L Yu ${ }^{1,2}$, Y Li ${ }^{1,2}$, P Wan ${ }^{3}$, LL Chen ${ }^{1,2}$, BH Jiang ${ }^{1,2}$, \\ LH Hu, ${ }^{\star, 1,2}, \mathrm{~J} \mathrm{Chen}^{\star, 1,2}$ and X Shen ${ }^{*, 1,2}$
}

Kv2.1 as a voltage-gated potassium (Kv) channel subunit has a pivotal role in the regulation of glucose-stimulated insulin secretion (GSIS) and pancreatic $\beta$-cell apoptosis, and is believed to be a promising target for anti-diabetic drug discovery, although the mechanism underlying the Kv2.1-mediated $\beta$-cell apoptosis is obscure. Here, the small molecular compound, ethyl 5-(3-ethoxy-4methoxyphenyl)-2-(4-hydroxy-3-methoxybenzylidene)-7-methyl-3-oxo-2,3-dihydro-5H-[1,3]thiazolo[3,2-a]pyrimidine-6-carboxylate (SP6616) was discovered to be a new Kv2.1 inhibitor. It was effective in both promoting GSIS and protecting $\beta$ cells from apoptosis. Evaluation of SP6616 on either high-fat diet combined with streptozocin-induced type 2 diabetic mice or $d b / d b$ mice further verified its efficacy in the amelioration of $\beta$-cell dysfunction and glucose homeostasis. SP6616 treatment efficiently increased serum insulin level, restored $\beta$-cell mass, decreased fasting blood glucose and glycated hemoglobin levels, and improved oral glucose tolerance. Mechanism study indicated that the promotion of SP6616 on $\beta$-cell survival was tightly linked to its regulation against both protein kinases C (PKC)/extracellular-regulated protein kinases 1/2 (Erk1/2) and calmodulin(CaM)/phosphatidylinositol 3kinase(PI3K)/serine/threonine-specific protein kinase (Akt) signaling pathways. To our knowledge, this may be the first report on the underlying pathway responsible for the Kv2.1-mediated $\beta$-cell protection. In addition, our study has also highlighted the potential of SP6616 in the treatment of type 2 diabetes.

Cell Death and Disease (2016) 7, e2216; doi:10.1038/cddis.2016.119; published online 5 May 2016

Type 2 diabetes mellitus (T2DM) is a chronic, complex and multifactorial metabolic disorder mainly characterized by hyperglycemia with insulin resistance and deficiency. T2DM has become a serious global health problem bringing heavy burdens to societies. ${ }^{1}$ Currently, a series of anti-T2DM drugs are being clinically used, but their existing side effects are still triggering the urgent need for novel agents in the treatment of this disease. ${ }^{1}$

Recently, accumulating evidence has revealed that pancreatic $\beta$-cell dysfunctions including glucose-stimulated insulin secretion (GSIS) defect and $\beta$-cell mass loss are major determinants for the progression from prediabetes with normoglycemia to diabetes with hyperglycemia, and the result that insulin resistance in prediabetes needs compensatory insulin hypersecretion likely leads to a progressive decline in islet $\beta$-cell function. ${ }^{2}$ Therefore, an ideal strategy for T2DM treatment is to improve pancreatic $\beta$-cell function. ${ }^{1,2}$

Numerous electrical signaling systems including $\mathrm{K}^{+}, \mathrm{Na}^{+}$, $\mathrm{Ca}^{2+}$ and $\mathrm{Cl}^{-}$fluxes across $\beta$-cell membranes have been determined to participate in the function and/or survival of pancreatic $\beta$ cells. ${ }^{3}$ There are three major potassium fluxes in $\beta$ cells, including $\mathrm{K}^{+}$effluxes regulated by voltage-gated $\mathrm{K}^{+}$ (Kvs) or ATP-sensitive $\mathrm{K}^{+}\left(\mathrm{K}_{\mathrm{ATP}}\right)$ channel and calciumactivated potassium channel $\left(\mathrm{KCa}^{2+}\right) .{ }^{3} \mathrm{Kv} 2.1$ as a voltagegated potassium (Kv) family member accounts for the majority of $\mathrm{Kv}$ currents in both rodent and human and negatively regulates GSIS. ${ }^{4}$ In $\beta$ cells, the ATP derived from glucose metabolism efficiently depolarizes $\beta$ cells leading to the opening of voltage-gated ion channels. ${ }^{3}$ Activated $\mathrm{K}^{+}$currents produce the repolarization of $\beta$-cell action potential resulting in the shutdown of voltage-dependent $\mathrm{Ca}^{2+}$ channels (VDCCs), abolishment of VDCC-mediated $\mathrm{Ca}^{2+}$ influx and blockage of insulin secretion. . $^{3,5}$

Reports have demonstrated that Kv2.1 signaling regulation is involved in the apoptosis processes of neuron and $\beta$ cells. ${ }^{6,7}$ For example, Kv2.1 overexpression activates the mitochondrial or ER stress-induced apoptosis ${ }^{6}$ and elevates the sensitivity of cells to apoptotic factors, ${ }^{7}$ whereas transient

\footnotetext{
${ }^{1}$ CAS Key Laboratory of Receptor Research, 3th Department of Pharmacology, Shanghai Institute of Materia Medica, Chinese Academy of Sciences, Shanghai, China; ${ }^{2}$ University of Chinese Academy of Sciences, Beijing, China and ${ }^{3}$ College of Life and Environmental Sciences, Shanghai Normal University, Shanghai, China *Corresponding author: LH Hu or J Chen or X Shen, CAS Key Laboratory of Receptor Research, 3th Department of Pharmacology, Shanghai Institute of Materia Medica, Chinese Academy of Sciences, 555 Zuchongzhi Road, Shanghai 201203, China or University of Chinese Academy of Sciences, No.19A Yuquan Road, Beijing 100049, China. Tel/Fax: +86 21 50806918; E-mail: Ihhu@simm.ac.cn or jingchen@simm.ac.cn or xshen@simm.ac.cn

${ }^{4}$ These two authors contributed equally to this work.

Abbreviations: T2DM, type 2 diabetes mellitus; GSIS, glucose-stimulated insulin secretion; MTT, 3-(4,5-dimethylthiazol-2-yl)-2,5-diphenyltetrazolium bromide; Kv, voltage-gated potassium; VDCCs, voltage-dependent $\mathrm{Ca}^{2+}$ channels; HFD, high-fat diet; STZ, streptozocin; ScTx-1, stromatoxin-1; Erk1/2, extracellular-regulated protein kinases 1/2; PKC, protein kinase C; PI3K, phosphatidylinositol 3-kinase; Akt, serine/threonine-specific protein kinase; XIAP, X-linked inhibitor of apoptosis protein; GAPDH, glyceraldehyde-3-phosphate dehydrogenase; OGTT, oral glucose tolerance test; HbA1c, glycated hemoglobin; KRB, Krebs-Ringer bicarbonate; FBS, fetal bovine serum; AUC, area under the curve; FoxO1, Forkhead box protein 01

Received 01.9.15; revised 07.4.16; accepted 11.4.16; Edited by M Agostini
} 

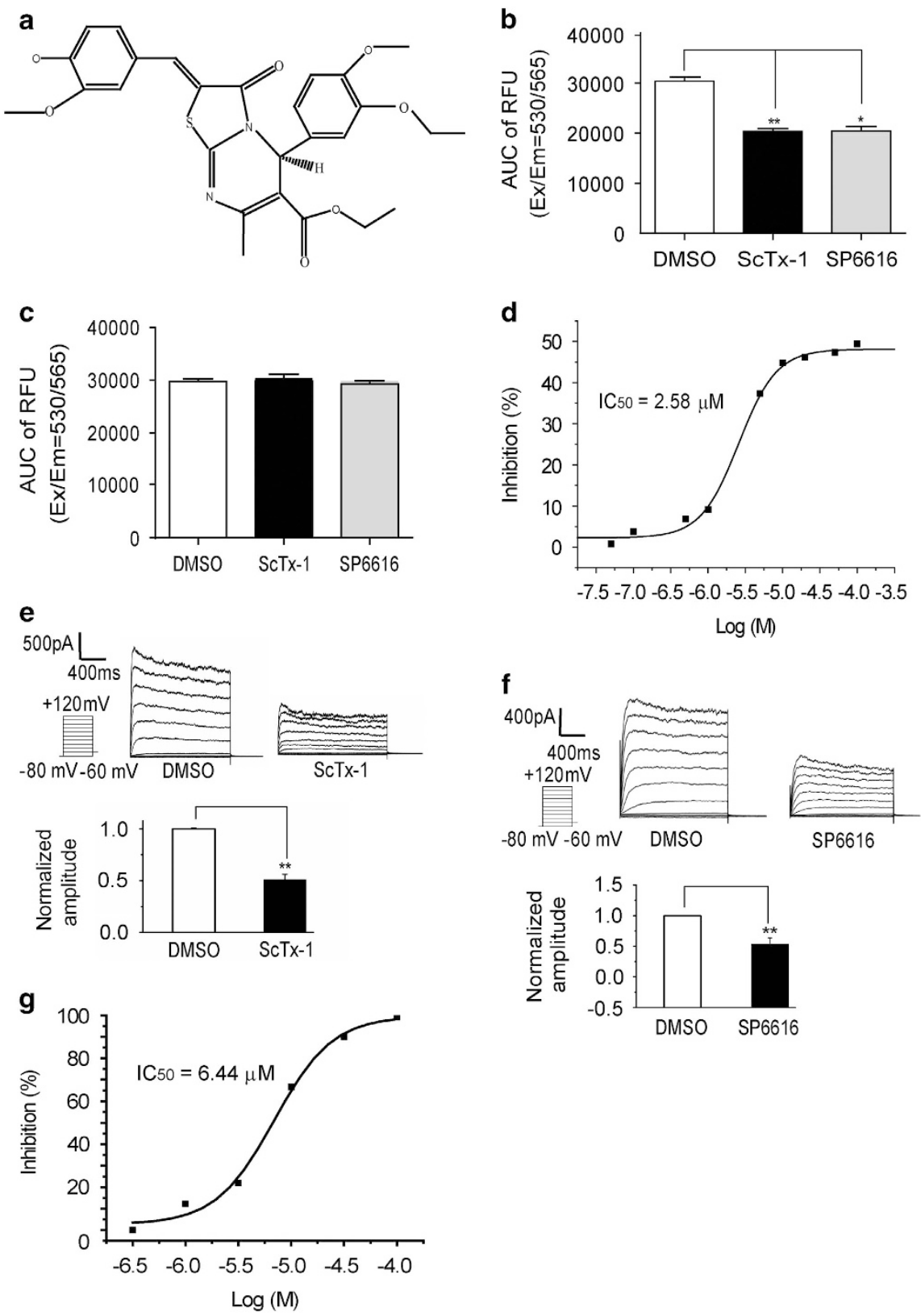

Figure 1 SP6616 is an inhibitor of Kv2.1 channel. (a) Chemical structure of SP6616. (b) CHO-Kv2.1 cells were incubated with $20 \mu \mathrm{M} \mathrm{SP6616}$ or $100 \mathrm{nM}$ ScTx-1 and membrane potential dye for $30 \mathrm{~min}$, and then signal was recorded. These data were analyzed and shown as AUC. (c) Membrane potential assay in CHO cells was conducted as described in b. (d) Fifty percent inhibitive concentration $\left(\mathrm{IC}_{50}, 2.58 \mu \mathrm{M}\right)$ of SP6616 evaluated on the membrane potential assay. (e) Voltage-dependent outward $\mathrm{K}^{+}$currents were recorded in CHO-Kv2.1 cells by whole-cell patch clamp from $-80 \mathrm{mV}$ to $+120 \mathrm{mV}$. ScTx-1 (100 nM) effectively reduced K ${ }^{+}$current amplitude. (f) SP6616 (10 $\mu$ M) inhibited $\mathrm{K}^{+}$current amplitude in the whole-cell patch clamp assay. (g) IC $\mathrm{C}_{50}(6.44 \mu \mathrm{M})$ of SP6616 was evaluated on whole-cell patch clamp technique. All data were obtained from three independent experiments and shown as means \pm S.E.M. $\left({ }^{*} P<0.05,{ }^{* *} P<0.01\right)$

expression of Kv2.1 function-deficient mutant avoids neuronal apoptosis. $^{7}$ Therefore, Kv2.1 channel is crucial to insulin secretion and/or $\beta$-cell apoptosis, and Kv2.1 inhibitors function potently in the promotion of insulin secretion and/or $\beta$-cell protection, ${ }^{8-10}$ although the mechanisms underlying the regulation of $\beta$-cell protection still remain unclear.

Here, the small molecule, ethyl 5-(3-ethoxy-4-methoxyphenyl)-2-(4-hydroxy-3-methoxybenzylidene)-7-methyl-3-oxo-2,3-dihydro-5H-[1,3]thiazolo[3,2-a]pyrimidine-6-carboxylate (SP6616,
Figure 1a) was found to be a new Kv2.1 inhibitor. It was capable of both promoting GSIS and protecting $\beta$ cells from apoptosis. Protein kinases C (PKC)/extracellular-regulated protein kinases 1/2 (Erk1/2) and calmodulin (CaM)/phosphatidylinositol 3-kinase (PI3K)/serine/threonine-specific protein kinase (Akt) pathways were first determined to be implicated in the Kv2.1-mediated $\beta$-cell protection. Moreover, assays on T2DM model mice high-fat diet (HFD)/streptozocin (STZ) and $d b / d b$ demonstrated that SP6616 efficiently ameliorated $\beta$-cell 
dysfunction and improved glucose homeostasis, further highlighting the potential of SP6616 in the treatment of T2DM.

\section{Results}

\section{SP6616 is a Kv2.1 inhibitor}

SP6616 inhibited membrane potential in $\mathrm{CHO}$ Kv2.1 cells: Given that the membrane potential-sensitive fluorescent dye is powerful for screening regulators of ion channels, ${ }^{11}$ the membrane potential (FLIPR membrane potential assay kit) based platform by FlexStationll384 was at first applied to screen Kv2.1 inhibitor candidates against the lab compound library. As shown in Figure 1b, Kv2.1 inhibitor ScTx-1 (stromatoxin-1,100 nM) ${ }^{12}$ obviously inhibited the membrane potential in $\mathrm{CHO}-\mathrm{Kv} 2.1$ cells, indicating the efficacy of this platform in screening Kv2.1 inhibitor candidates.

Accordingly, SP6616 was discovered to be active in inhibiting membrane potential in $\mathrm{CHO}-\mathrm{Kv} 2.1$ cells (Figure 1b) by $\mathrm{IC}_{50}$ at $2.58 \mu \mathrm{M}$ (Figure $1 \mathrm{~d}$ ). Moreover, the result that neither SP6616 $(20 \mu \mathrm{M})$ nor ScTx-1 (100 nM) inhibited membrane potential in normal $\mathrm{CHO}$ cells further confirmed the inhibition of SP6616 against Kv2.1 channel (Figure 1c). In addition, SP6616 was also found to inhibit Kv2.2 channel by $I_{50}$ at $13.48 \mu \mathrm{M}$ (Supplementary Figure 1) in $\mathrm{CHO}$ cells transfected with pcDNA3.1a-Kv2.2, this result thus indicated the slightly preferred selectivity of SP6616 against Kv2.1 over Kv2.2.

Patch clamp assay confirmed SP6616 inhibition against KV2.1 channel: To verify SP6616 inhibition against Kv2.1 channel, the classical whole-cell patch clamp assay was performed in $\mathrm{CHO}-\mathrm{Kv} 2.1$ cells. The results indicated that SP6616 inhibited $\mathrm{Kv} 2.1$ channel by $\mathrm{IC}_{50}$ at $6.44 \mu \mathrm{M}$ (Figures $1 \mathrm{f}$ and $\mathrm{g}$ ), in which ScTx-1 (100 nM) was used as a positive control (Figure 1e).

Therefore, all results have determined that SP6616 was a Kv2 inhibitor with slight selectivity against Kv2.1 over Kv2.2.

SP6616 improves $\beta$-cell dysfunction in a Kv2.1-dependent manner. Given that Kv2.1 inhibition mediates potently in ameliorating pancreatic $\beta$-cell dysfunction, ${ }^{6,9}$ the effects of SP6616 on GSIS and $\beta$-cell survival were investigated in INS-832/13 cells.

SP6616 promoted GSIS: GSIS assay was conducted relating to the effect of SP6616 on insulin secretion. As shown in Figure 2a (ScTx-1 and glibenclamide as positive controls), SP6616 dosedependently activated insulin secretion in response to high concentration of glucose $(16.8 \mathrm{mM})$ stimulation.

To verify the dependency of Kv2.1 inhibition for SP6616potentiated GSIS, the dominant-negative mutant of Kv2.1 $(\mathrm{Kv} 2.1 \mathrm{~N})^{9,10}$ involved assay was performed. As shown in Figure 2b, transfection of Kv2.1N caused inability of SP6616 or ScTx-1 in promoting GSIS, implying that SP6616 enhanced GSIS in a Kv2.1-dependent manner.

SP6616 protected $\beta$ cells from STZ-induced apoptosis: Next, we investigated the potential protection of SP6616 against $\beta$-cell apoptosis by 3-(4,5-dimethylthiazol-2-yl)-2,5-diphenyltetrazolium bromide (MTT) assay with STZ $(0.4 \mathrm{mM})$ as cell apoptosis stimulus. ${ }^{13}$ As shown in Figure 2c, SP6616 had no effects on $\beta$-cell viability but counteracted the STZ-induced cell apoptosis in INS-832/13 cells. In addition, SP6616 also exhibited activity in antagonizing the STZinduced increases in both the protein level of cleaved caspase 3 (pro-apoptosis protein) and the activity of caspase 3/7 (Promega, Madison, WI, USA) (Figures 2d-f), further confirming that SP6616 could protect $\beta$-cell from apoptosis. Moreover, Kv2.1N transfection resulted in the inactivity of SP6616 in protection against STZ-induced apoptosis (Figure 2g). Thus, these results showed that SP6616 protected $\beta$ cells from apoptosis in a Kv2.1-dependent manner.

It is noted that the published reports indicated that Kv2.1N transfection in rat islet reduced approximately 60\%-outward $\mathrm{K}^{+}$currents, ${ }^{9,14}$ while in the current work, the effects of SP6616 were almost fully abolished in Kv2.1N-transfected cells. Such a discrepancy may be caused by the signal transduction from current blockage to insulin secretion or antiapoptosis in cells. Similarly, such a non-linear relationship between current blockage and insulin secretion has been also reported elsewhere. .,10 $^{\circ}$

Taken together, SP6616 was a new Kv2.1 inhibitor with dual effects on both insulin secretion promotion and $\beta$-cell protection.

Potentiation of SP6616 on GSIS links to glucosestimulated $\mathrm{Ca}^{2+}$ influx. Considering that $\mathrm{Kv}$ channel activation can induce membrane repolarization and VDCCs closure further reducing insulin secretion and $\mathrm{K}_{\mathrm{V}}$ channel inhibition heightens intracellular $\mathrm{Ca}^{2+}$ level and stimulates insulin secretion, ${ }^{3,5}$ we next detected intracellular $\mathrm{Ca}^{2+}$ level mediated by SP6616 in INS-832/13 cells. As shown in Figure $2 \mathrm{~h}$, either ScTx-1(100 nM) or SP6616 $(10 \mu \mathrm{M})$ increased intracellular $\mathrm{Ca}^{2+}$ level in the presence of $16.8 \mathrm{mM}$ glucose. And such an intracellular $\mathrm{Ca}^{2+}$ increase was blocked by depleting extracellular calcium in Hank's balanced salt solution (HBSS) buffer or by nifedipine (L-VDCC blocker) ${ }^{15}$ (Figures $2 \mathrm{i}$ and j). These results thereby revealed that SP6616-stimulated $\mathrm{Ca}^{2+}$ influx in response to high glucose, similar to the published $\mathrm{K}_{\mathrm{V}}$ channel inhibitionmediated GSIS event. ${ }^{16}$

$\mathrm{Ca}^{2+}$ influx/PKC/Erk1/2 and $\mathrm{Ca}^{2+}$ influx/CaM/PI3K/Akt pathways are responsible for SP6616-mediated $\beta$-cell survival. Apoptosis is the process of programmed cell death, and regulated by a variety of extrinsic factors. ${ }^{17}$ Although the signaling pathways in apoptosis are complicated, signaling of Erk1/2, p38, JNK, Akt or NFKB is determined to be vital in apoptosis and proliferation. ${ }^{17,18}$ Therefore, we examined whether SP6616-mediated $\beta$-cell survival was implicated in any of those five signaling pathways in INS-832/13 cells. As demonstrated in Figures $3 a$ and b, SP6616 reversed the STZ-induced decrease of either Erk1/2 or Akt phosphorylation, but rendered no effects on $\mathrm{p} 38$, JNK or NFKB phosphorylation (Supplementary Figure 2). Accordingly, we next investigated SP6616 protection against $\beta$ cells by focusing on Erk $1 / 2$ and Akt signaling. 
a

$$
\text { a } \frac{\text { a }}{3}
$$

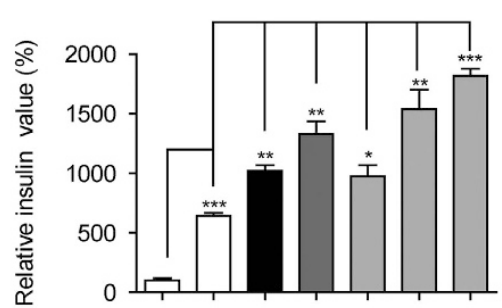

Glucose $(16.8 \mathrm{mM})+++++$

Glibenclamide $(0.5 \mu \mathrm{M})$

ScTx-1 (100 nM)

SP6616 $(\mu \mathrm{M})$

c

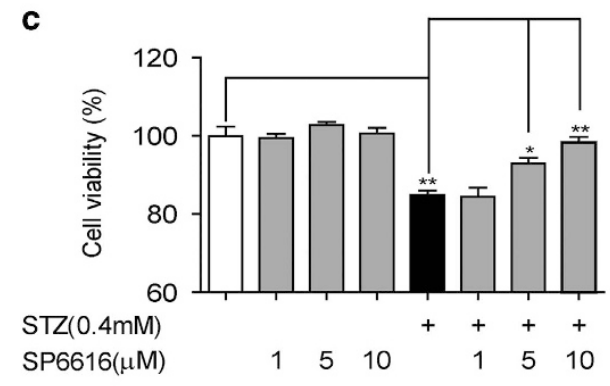

b

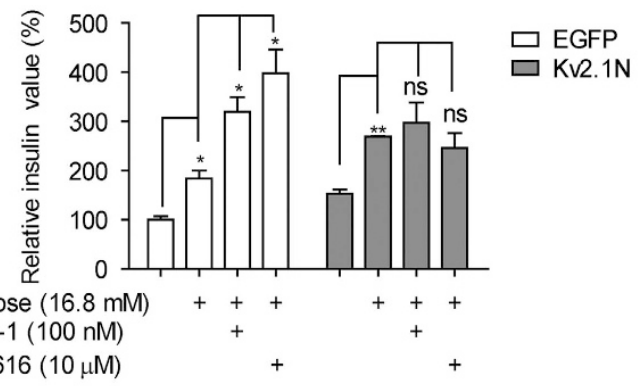

d

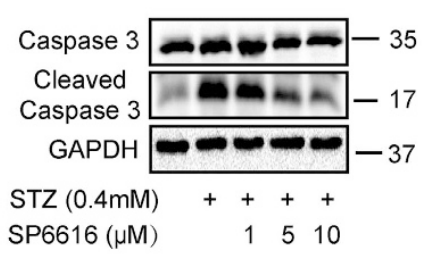

e

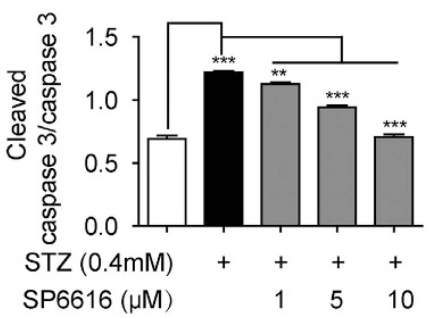

f

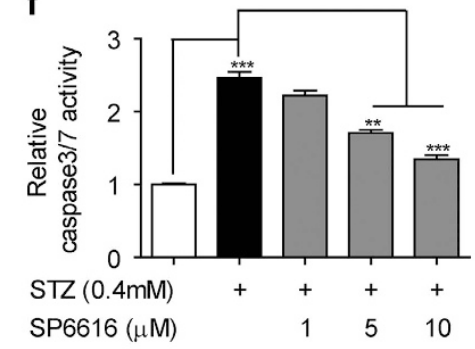

g

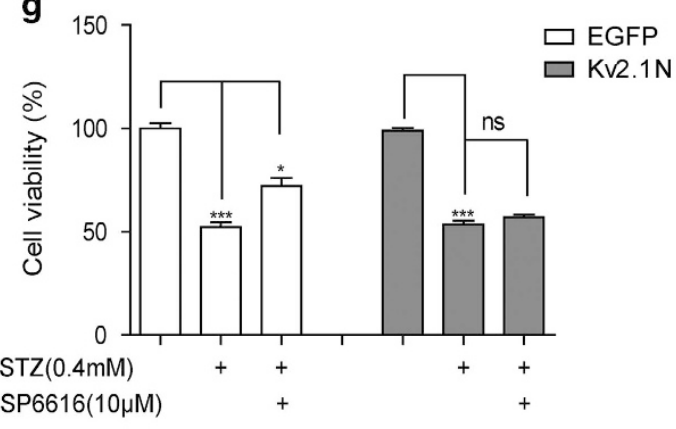

h

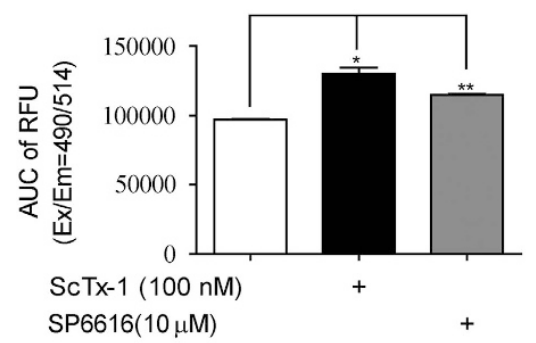

i

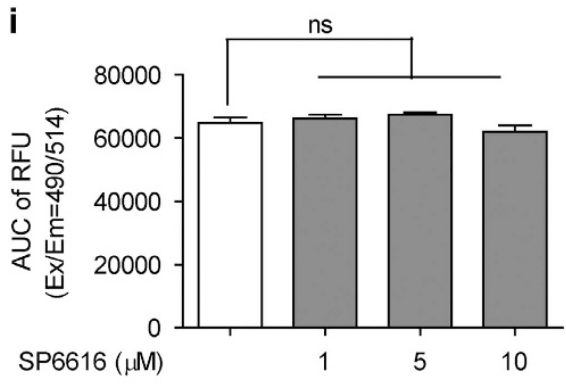

j

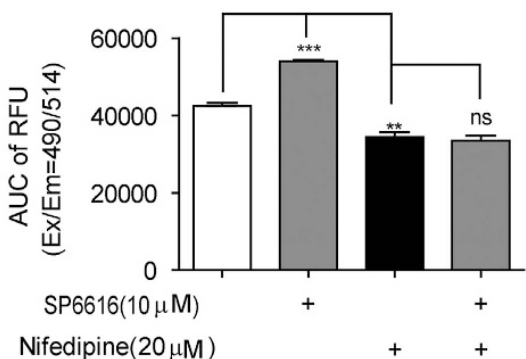

Figure 2 SP6616 improves pancreatic $\beta$-cell dysfunction by inhibiting Kv2.1 channel. (a) After 2-h incubation with glucose-free KRB buffer, INS-832/13 cells were incubated with SP6616 $(1,5,10 \mu \mathrm{M}), \mathrm{ScTx}-1$ (100 nM) or glibenclamide $(0.5 \mu \mathrm{M})$ in the presence of $16.8 \mathrm{mM}$ glucose in KRB buffer, and insulin secretion was then detected by AlphaLISA insulin kit. (b) INS-832/13 cells were transfected with Kv2.1N or EGFP (control), and incubated with glucose-free KRB buffer for $2 \mathrm{~h}$. The cells were stimulated with SP6616 $(10 \mu \mathrm{M})$ or ScTx-1 (100 nM) in KRB buffer with $16.8 \mathrm{mM}$ glucose, and insulin secretion was detected. (c) INS-832/13 cells were incubated with different concentrations of SP6616 $(1,5,10 \mu \mathrm{M})$ in the absence or presence of STZ $(0.4 \mathrm{mM})$ for $24 \mathrm{~h}$, and then MTT assay was conducted. (d) INS-832/13 cells were treated with SP6616 $(1,5,10 \mu \mathrm{M})$ and STZ $(0.4 \mathrm{mM})$ for $8 \mathrm{~h}$, and the cell lysate was then analyzed by western blot assay using caspase 3 antibody. (e) Relative protein levels of cleaved caspase $3 / \mathrm{caspase} 3$ in $\mathrm{d}$. (f) INS-832/13 cells were treated with SP6616 $(1,5,10 \mu \mathrm{M})$ and STZ $(0.4 \mathrm{mM})$ for $8 \mathrm{~h}$, and then caspase $3 / 7$ activity was detected. (g) INS-832/13 cells were transfected with Kv2.1N or EGFP, and incubated with SP6616 $(10 \mu \mathrm{M})$ and STZ $(0.4 \mathrm{mM})$ for $24 \mathrm{~h}$, followed by MTT assay. (h) Intracellular Ca $\mathrm{Ca}^{2+}$ level in INS-832/13 cells was monitored by Fluo-8 AM fluorescence dye. The cells were pre-incubated in KRB buffer for $2 \mathrm{~h}$ and then the plate was loaded on FlexStationll384. The baseline fluorescence signal was measured for the first $20 \mathrm{~s}$, and then stimulated with $16.8 \mathrm{mM}$ glucose in the presence of SP6616 $(10 \mu \mathrm{M})$ or ScTx-1 $(100 \mathrm{nM})$. These data were shown as AUC of intracellular Ca ${ }^{2+}$ change. (i) The intracellular $\mathrm{Ca}^{2+}$ assay was conducted as ( $h$ ) in calcium-free HBSS buffer. (j) The intracellular $\mathrm{Ca}^{2+}$ assay involving nifedipine was conducted as $\mathrm{h}$. All data were obtained from three independent experiments and presented as means \pm S.E.M. $\left({ }^{\star} P<0.05,{ }^{* \star} P<0.01,{ }^{* \star \star} P<0.001\right.$; ns, no significance) 
Erk1/2 signaling was implicated in SP6616-mediated $\beta$-cell protection: To investigate SP6616 regulation against Erk1/2 signaling, Erk1/2 phosphorylation ( $p$-Erk1/2) levels under different concentrations of SP6616 were examined. As shown in Figures 3c-f, SP6616 did not affect p-Erk1/2 but reversed the STZ-induced decrease of the phosphorylation level, and such an effect was terminated by U0126 (MEK/ Erk1/2 inhibitor) ${ }^{13}$ treatment. These results thereby showed the regulation of SP6616 against Erk1/2. Moreover, Kv2.1N transfection caused inactivity of SP6616 in antagonizing the STZ-induced decrease in p-Erk1/2 in INS-832/13 cells (Figures $3 \mathrm{~g}$ and $\mathrm{h}$ ), thus confirming the Kv2.1-dependent regulation of SP6616 against Erk1/2 in the cells.

$\mathrm{Ca}^{2+}$ influx and PKC phosphorylation were in the upstream of Erk1/2 phosphorylation in response to SP6616 regulation: Reports demonstrated that the increase of intracellular $\mathrm{Ca}^{2+}$ promotes PKC phosphorylation, Ras/mitogen-activated protein kinase (MAPK) signaling cascade and Erk1/2 phosphorylation leading to the protection of cells from apoptosis. ${ }^{19}$ Given that SP6616-induced $\mathrm{Ca}^{2+}$ influx under high glucose stimulation, the regulations of SP6616 against intracellular $\mathrm{Ca}^{2+}$ level and PKC phosphorylation with STZ treatment were investigated. It was found that SP6616 had no effects on $\mathrm{Ca}^{2+}$ influx, but could reverse the STZ-induced decreases both in intracellular $\mathrm{Ca}^{2+}$ level (Figure 3i) and PKC phosphorylation (Figures 3j and k). These results thus indicated that SP6616 may induce $\mathrm{Ca}^{2+}$ influx and activate PKC to stimulate Erk1/2 phosphorylation in INS-832/13 cells. Moreover, the regulation of SP6616 against PKC/Erk1/2 pathway was further verified by the assay involving PKC pan-inhibitor GF109203X $(G F X),{ }^{20}$ in that GFX resisted the effects of SP6616 on Erk1/2 phosphorylation (Figures $3 \mid-n$ ). Interestingly, GFX itself increased $p$-Erk1/2 in INS-832/13 cells (Supplementary Figure 3), whereas the published results indicated that GFX exhibited no effects on $\mathrm{p}$-Erk1/2 in the cells with treatment of glucose or IGF-1. ${ }^{21}$ We here tentatively supposed that such a discrepancy may be due to the different experimental conditions.

Taken together, $\mathrm{Ca}^{2+}$ influx/PKC/Erk1/2 pathway was determined to be involved in the protection of SP6616 against STZ-induced $\beta$-cell apoptosis.

SP6616 regulated Akt and its downstream effectors Forkhead box protein 01 (FoxO1), X-linked inhibitor of apoptosis protein $(X I A P)$ and Bad: Next, we investigated the regulation of SP6616 against Akt signaling in INS-832/13 cells. As shown in Figures $4 a$ and b, SP6616 had no effects on Akt phosphorylation (p-Akt) but reversed the STZ-induced decrease in p-Akt. Notably, incubation of wortmannin (PI3K

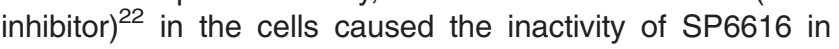
recovering the STZ-reduced Akt phosphorylation (Figures 4c and $d$ ). These results thereby implied the regulation of SP6616 against Akt signaling. In addition, to determine whether the SP6616-increased p-Akt was dependent on Kv2.1 regulation, the relevant assays in Kv2.1N-transfected INS-832/13 cells were performed. As illustrated in Figures $4 \mathrm{e}$ and $f$, the ability of SP6616 in reversing the STZ-decreased p-Akt weakened, this result thereby indicated that SP6616- stimulated Akt phosphorylation in a Kv2.1-dependent manner.

Given that the effectors involved in Akt-mediated antiapoptotic pathways mainly include FoxO1, Bad and XIAP in $\beta$ cells, ${ }^{23}$ we next examined the potential regulation of SP6616 against these three downstream proteins. As shown in Figures $4 \mathrm{~g}-\mathrm{j}$, SP6616 reversed the STZ-induced decreases in phosphorylated FoxO1 ( $p$-Ser256)/Bad ( $p$-Ser136) and protein level of XIAP. Moreover, western blot results (Figures $4 k-n)$ showed that wortmannin treatment could block all above SP6616-induced effects, thus addressing the dependence of the regulation against $A k t$ in the signaling.

$\mathrm{Ca}^{2+}$ influx and CaM activation were in the upstream of SP6616-stimulated Akt phosphorylation: Given that cytosolic-free calcium activates PI3K/Akt pathway through regulation of $\mathrm{CaM}^{24,25}$ and SP6616-induced $\mathrm{Ca}^{2+}$ influx, we next investigated whether CaM stimulation linked Kv2.1 inhibition to PI3K/Akt pathway activation in INS-832/13 cells. As indicated in Figures 40 and $p$, incubation of CaM antagonist chlorpromazine $(\mathrm{CPZ})^{26}$ caused almost the inactivity of SP6616 in reversing the STZ-reduced Akt phosphorylation.

Therefore, all results showed that both $\mathrm{Ca}^{2+}$ influx/PKC/ Erk1/2 and $\mathrm{Ca}^{2+}$ influx/CaM/PI3K/Akt signaling pathways were involved in SP6616-mediated $\beta$-cell protection.

PKC/Erk1/2 and CaM/PI3K/Akt pathways were required in parallel for SP6616 protection against $\beta$ cells: As either PKC/Erk1/2 or CaM/PI3K/Akt pathway has been determined to be involved in the protection of SP6616 against $\beta$-cell apoptosis, we next examined whether these two signaling pathways were required for the SP6616-induced protection against the cells. MTT assay was at first carried out. As indicated in Figures $5 a-c$, treatment with either U0126 (Figure 5a) or wortmannin (Figure 5b) in the cells failed to deprive SP6616 of its capability in protecting cell viability against the STZ-induced apoptosis. However, co-incubation of both U0126 and wortmannin (Figure 5c) in the cells almost blocked such SP6616-induced protection. Moreover, the results in quantitative evaluation of apoptosis by Annexin V-FITC staining further confirmed that SP6616 attenuated STZ-induced apoptosis and co-incubation of both U0126 and wortmannin in the cells could block this attenuation (Figures $5 \mathrm{~d}$ and $\mathrm{e}$ ).

Therefore, all results implied that PKC/Erk1/2 and CaM/ $\mathrm{PI}$ KK/Akt pathways were required in parallel for the SP6616induced $\beta$-cell survival promotion as summarized in Figure $8 \mathrm{e}$.

SP6616 ameliorates hyperglycemia in type 2 diabetic model mice. As SP6616 has been determined to promote GSIS and $\beta$-cell survival, we next examined its activity in amelioration of hyperglycemia on type 2 diabetic model mice. In the assay, the model mice HFD/STZ and $d b / d b$ were applied, and the male mice were administered with SP6616 (50 mg/kg/day) or vehicle by i.p. injection for 5 weeks. The results showed that SP6616 administration lowered the fasting blood glucose and glycated hemoglobin (HbA1c) levels (Figures 6a-d), and improved the glucose tolerance (Figures 6e-h) and insulin secretion during oral glucose tolerance test (OGTT; Figures $6 \mathrm{i}$ and $\mathrm{j}$ ) in both models. 
Therefore, all results suggested that SP6616 effectively ameliorated hyperglycemia in type 2 diabetic mice.

SP6616 promotes insulin secretion and $\beta$-cell mass in type 2 diabetic model mice. Considering that SP6616 improved $\beta$-cell dysfunction by promoting insulin secretion and protecting $\beta$ cell from apoptosis, we next evaluated the potential of this agent in stimulating plasma insulin content and insulin-positive islet mass in both the two diabetic mice. As expected, SP6616-treated groups possessed higher serum insulin levels (Figures $7 a$ and b) and more insulinpositive islets compared with vehicle groups (Figures $7 c-f$ ).

SP6616 regulates Erk1/2 and Akt signaling in vivo. In view of the cell-based result that PKC/Erk1/2 and CaM/PI3K/ Akt pathways were responsible for SP6616-mediated $\beta$-cell

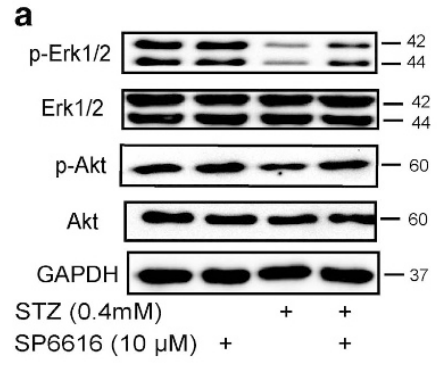

d

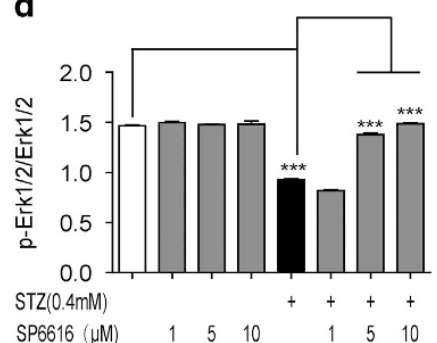

g

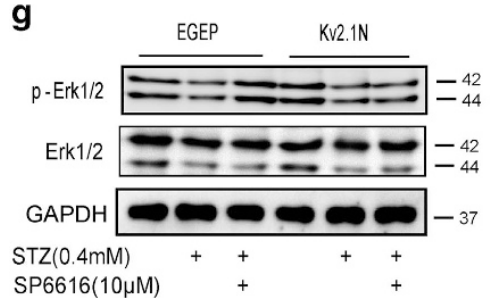

j
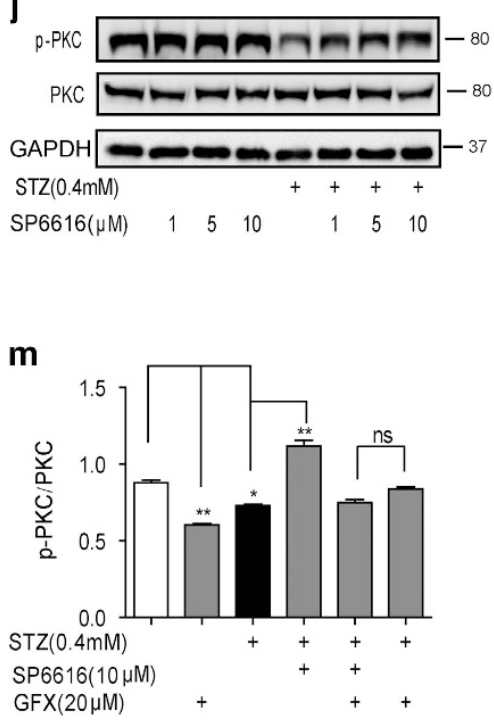

b

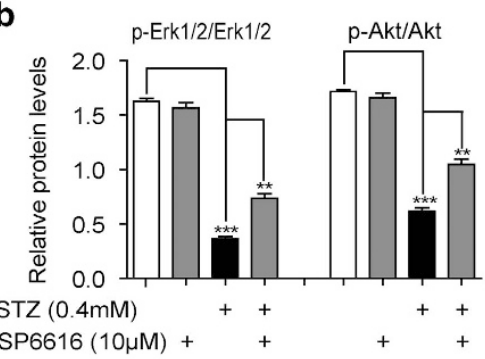

e

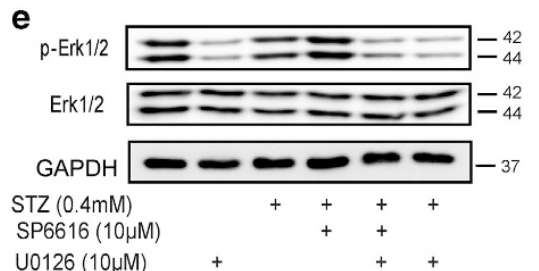

h

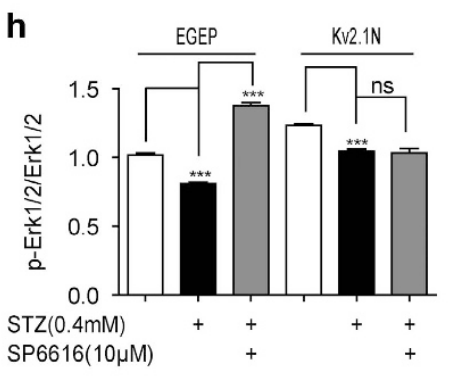

k

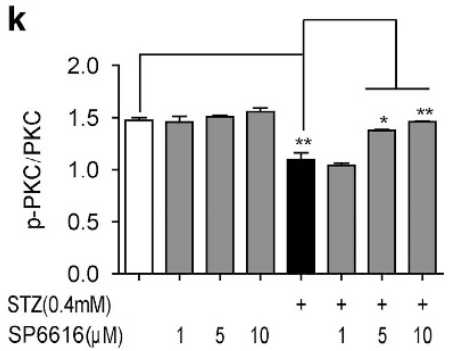

ก

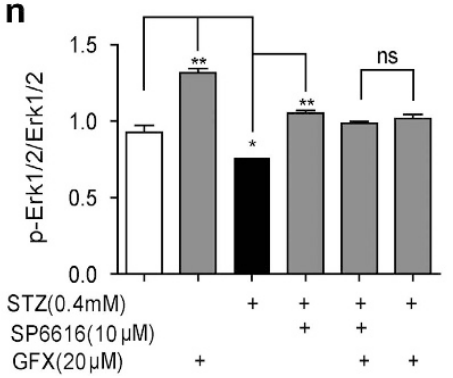

C

p- Erk1/2

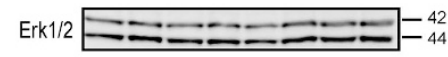

GAPDH

STZ(0.4mM)

$\begin{array}{lllllll}\operatorname{SP} 6616(\mu \mathrm{M}) & 1 & 5 & 10 & 1 & 5 & 10\end{array}$

f
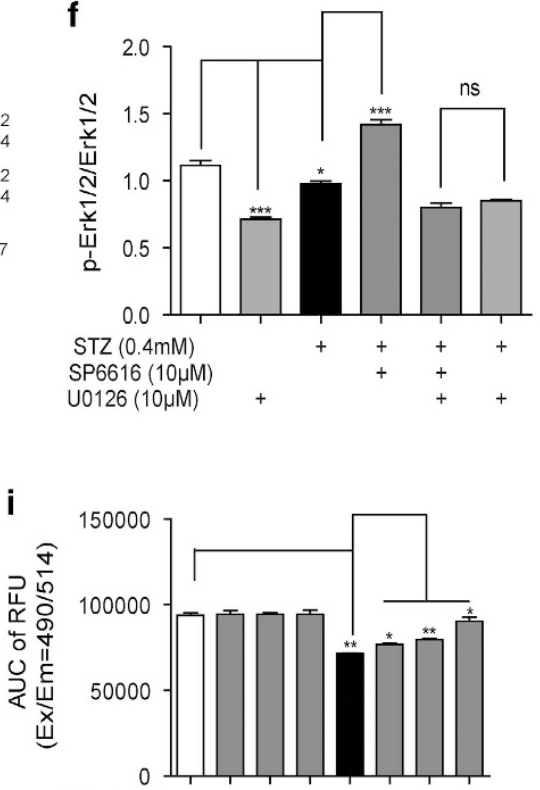

$\mathrm{STZ}(0.4 \mathrm{mM})$ $\mathrm{SP} 6616(\mu \mathrm{M})$

I

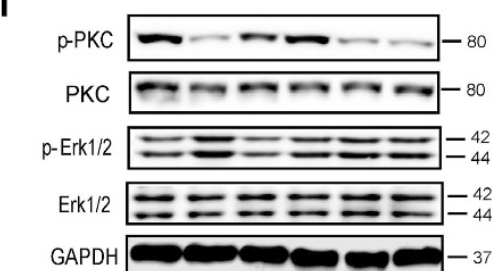

$\mathrm{STZ}(0.4 \mathrm{mM})$

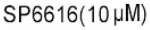

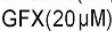


protection, we next evaluated SP6616 regulation against these two pathways in vivo. In the assay, the pancreatic tissues of both diabetic model mice were assayed by western blot against the key proteins involved in the pathways. As shown in Figures 8a-d, SP6616 administration in either model caused the increases in phosphorylated PKC, Erk1/2, Akt, FoxO1 and Bad and protein level of XIAP, totally consistent with the cell-based results, confirming the involvements of both Erk1/2 and Akt signaling in the protection of SP6616 against pancreatic $\beta$ cells.

\section{Discussion}

Kv2.1 channel is widely expressed in mammalian tissues including cardiomyocytes, muscles, brain and pancreatic $\beta$ cells. ${ }^{27}$ As a major Kv family member, Kv2.1 channel contributes to $65-80 \%$ of the total Kv currents in human and rodent $\beta$ cells. It has a crucial role in pancreatic $\beta$-cell membrane repolarization and its function. ${ }^{3,4,9}$ The fact that Kv2.1 inhibition promotes insulin secretion in response to high glucose implies the possibility in avoiding the side effect of hypoglycemia. ${ }^{28,29}$ Besides, Kv2.1 also functions potently in the regulation of cell apoptosis although the underlying mechanisms have not yet been unveiled. ${ }^{7}$

Currently, several kinds of Kv2.1 inhibitors have been discovered. For example, peptide-type inhibitors include hanatoxin, guangxitoxin-1E, heteroscordratoxins, ScTx-1, SGTx1, syntaxin-1A, SsmTx-I and plasma gelsolin. ${ }^{30-36}$ Small molecular inhibitors galantamine and isoliquiritigenin block Kv2.1 currents with little data on GSIS or cell apoptosis; ${ }^{37,38}$ RY796 and C-1 enhance GSIS; ${ }^{8,9}$ donepezil and 48F10 abolish neuronal apoptosis. ${ }^{39,40}$ Previously, we reported natural product vindoline functioned in promotion of both insulin secretion and $\beta$-cell protection. ${ }^{10} \mathrm{SP} 6616$ is a new kind of small molecular Kv2 inhibitor with slight selectivity against Kv2.1 over Kv2.2 sharing totally different structure with the published inhibitors. Structurally, SP6616 possesses $(1,3)$ thiazolo(3,2-a)pyrimidine scaffold whose derivatives are known to exhibit varied biological activities, including antiviral, anti-neoplastic, anti-bacterial and anti-inflammatory. ${ }^{41}$ Our current work has further expanded the pharmacological applications of this kind of compound. To our knowledge, SP6616 and vindoline may be the only two small molecular Kv2.1 inhibitors able to both promote insulin secretion and survival. Moreover, SP6616 as a new Kv2.1 inhibitor effectively ameliorates $\beta$-cell dysfunction and improves glucose homeostasis in vivo. All these results have highlighted the potential of SP6616 in the treatment of type 2 diabetes.

It is accepted that activation of Kv channel can inhibit insulin secretion by inducing membrane repolarization and closure of VDCCs, and $\mathrm{K}_{\mathrm{V}}$ inhibition stimulates insulin secretion. ${ }^{3,5}$ Here, we found that SP6616 as a Kv2.1 inhibitor effectively stimulated GSIS by following this underlying mechanism.

$\mathrm{Ca}^{2+}$ is a ubiquitous cellular signaling molecule controlling a variety of cellular processes including cell survival. ${ }^{42}$ PKC isoform as a downstream transducer of $\mathrm{Ca}^{2+}$ participates in multifarious signaling pathways of biological processes including survival, proliferation, tumorigenesis and angiogenesis. ${ }^{43}$ Erk1/2 is an important member of the MAPK family and has a critical role in pancreatic $\beta$ cells, particularly in the regulation of proliferation and survival. ${ }^{44,45} \mathrm{An}$ increase of intracellular $\mathrm{Ca}^{2+}$ can evoke PKC activation in triggering Erk1/2 stimulation. ${ }^{19} \mathrm{CaM}$, a loop-helix-loop $\mathrm{Ca}^{2+}$-binding protein as another downstream transducer of $\mathrm{Ca}^{2+}$ potently regulates multiple processes in eukaryotic cells, like proliferation and growth. ${ }^{46}$ Besides, increase of intracellular-free $\mathrm{Ca}^{2+}$ activates PI3K/Akt signaling via CaM in different cell lines. ${ }^{24,25}$ $\mathrm{PI}$ 3K/Akt pathway is known to promote survival of many cell lines, the anti-apoptotic targets of Akt signaling mainly include FoxO1, Bad and XIAP in $\beta$ cells. ${ }^{23}$ FoxO1 is a transcription factor regulating cellular processes like glucose metabolism, apoptosis, cell cycle regulation and DNA damage repair. ${ }^{47}$ Phosphorylation of FoxO1 regulated by Akt promotes its nuclear exclusion and inhibits its pro-apoptosis function. ${ }^{48}$ Besides, Akt inactivates the pro-apoptotic activity of Bad by mediating the phosphorylation at Ser136. ${ }^{23}$ Akt has also been shown to promote cell survival by enhancing the stability of $\mathrm{XIAP}^{49}$ which is one of the conserved family of IAP that suppresses apoptosis by directly binding and inhibiting caspases activity. ${ }^{50}$ Here, we have well determined the regulation of SP6616 against the STZ-reduced intracellular $\mathrm{Ca}^{2+}$ and phosphorylation levels or protein levels of the related effectors such as PKC, Erk1/2, Akt, FoxO1, Bad and XIAP both in vitro and in vivo. All results have clearly expounded the potential mechanisms underlying SP6616 protection against $\beta$ cells. To our knowledge, PKC/Erk1/2 and CaM/PI3K/Akt may be the first reported pathways linked to the regulation of Kv2.1-mediated $\beta$-cell protection. Interestingly, $\mathrm{Bcl}-2$ has a central role in eukaryotic cell survival by inhibiting cell death, but $\mathrm{Bcl}-2$ regulation is here probably not involved in the

Figure $3 \mathrm{Ca}^{2+}$ influx/PKC/Erk1/2 signaling pathway is involved in the SP6616-mediated $\beta$-cell protection. (a) INS-832/13 cells were incubated with SP6616 (10 $\left.\mu \mathrm{M}\right)$ in the presence or absence of STZ $(0.4 \mathrm{mM})$ for $24 \mathrm{~h}$, and the cell lysate was analyzed by western blot assay using the corresponding antibodies. (b) Relative protein levels of $p$-Erk $1 / 2 /$ Erk1/2 and p-Akt/Akt in a. (c) INS-832/13 cells were incubated with SP6616 $(1,5,10 \mu \mathrm{M})$ in the presence or absence of STZ $(0.4 \mathrm{mM})$ for $24 \mathrm{~h}$, and the cell lysate was analyzed by western blot assay using $\mathrm{p}$-Erk1/2 and Erk1/2 antibodies. (d) Relative protein levels of $\mathrm{p}$-Erk1/2/Erk1/2 in c. (e) After INS-832/13 cells were incubated with SP6616 (10 $\mu \mathrm{M}$ ) and STZ $(0.4 \mathrm{mM})$ in the presence or absence of $\mathrm{U} 0126(10 \mu \mathrm{M})$ for $24 \mathrm{~h}$, the cell lysate was analyzed by western blot assay using p-Erk1/2 and Erk $1 / 2$ antibodies. (f) Relative protein levels of $p$-Erk1/2/Erk1/2 in e. (g) INS-832/13 cells were transfected with Kv2.1 N or EGFP, and incubated with STZ (0.4 mM) and SP6616 (10 $\mu \mathrm{M})$ or STZ alone, then the cell lysate was analyzed by western blot using p-Erk1/2 and Erk1/2 antibodies. (h) Relative protein levels of p-Erk1/2/Erk1/2 in g. (i) INS-832/13 cells were incubated with SP6616 (1, $5,10 \mu \mathrm{M})$ in the presence or absence of STZ $(0.4 \mathrm{mM})$ for $24 \mathrm{~h}$, then intracellular $\mathrm{Ca}^{2+}$ level were monitored by Fluo-8 AM fluorescence dye. Data were shown as the AUC of intracellular $\mathrm{Ca}^{2+}$ level. (j) INS-832/13 cells were incubated with SP6616 $(1,5,10 \mu \mathrm{M})$ in the presence or absence of STZ $(0.4 \mathrm{mM})$ for $24 \mathrm{~h}$, and the cell lysate was analyzed by western blot using p-PKC and PKC antibodies. (k) Relative protein levels of p-PKC/PKC in j. (I) INS-832/13 cells were incubated with SP6616 (10 $\mu \mathrm{M})$ and STZ (0.4 mM) in the presence or absence of GFX $(20 \mu \mathrm{M})$ for $24 \mathrm{~h}$, and the cell lysate was analyzed by western blot using corresponding antibodies. (m) Relative protein levels of $\mathrm{p}$-PKC/PKC in I. (n) Relative protein levels of $p$-Erk1/2/Erk1/2 in I. All data were obtained from three independent experiments and presented as means $\pm S . E . M . ~\left({ }^{\star} P<0.05\right.$, ${ }^{\star \star} P<0.01$, ${ }^{* * \star} P<0.001$; ns, no significance) 
SP6616-mediated $\beta$-cell protection (Supplementary Figure 4), which may be due to the insensitivity of $\mathrm{Bcl}-2$ against this apoptotic event. ${ }^{51}$

Given that Kv2.1 channel is also highly expressed in mammalian cardiomyocytes ${ }^{27}$ and cardiotoxicity evaluation is vital for drug development, the potential effect of
SP6616 on cardiac function in normal mice was also examined in the current work. As indicated in electrocardiography assay (Supplementary Figure 5), acute administration of SP6616 slightly prolonged QT intervals without affecting heart rates, which is consistent with the report that QT intervals are obviously prolonged without effect on heart rates in mice a

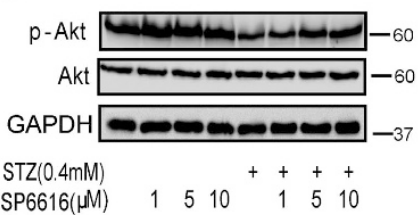

e

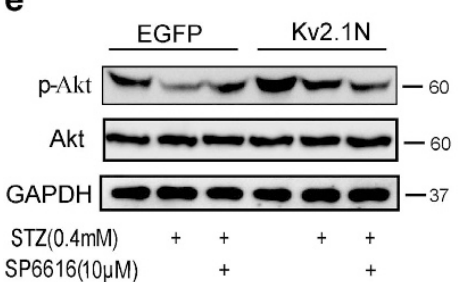

h

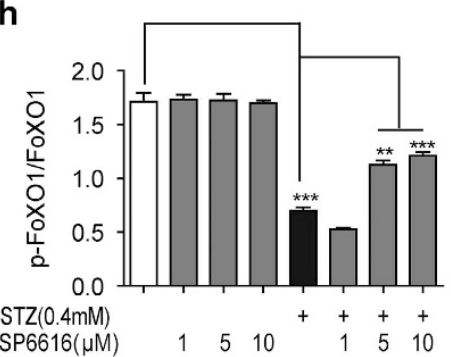

k

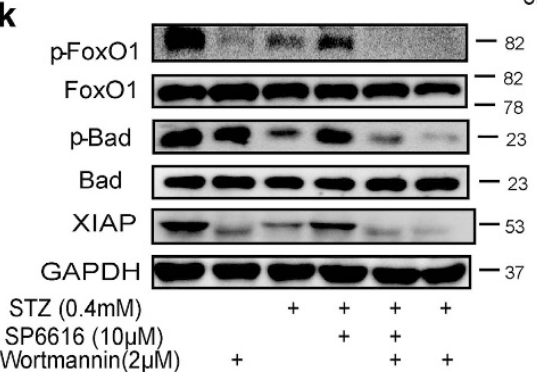

n

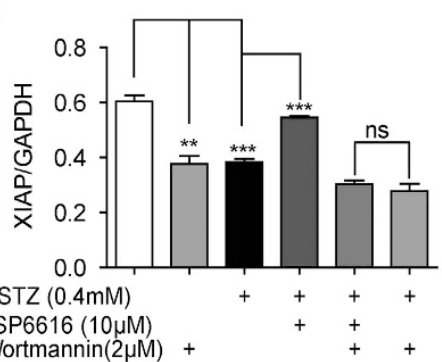

b

f

i

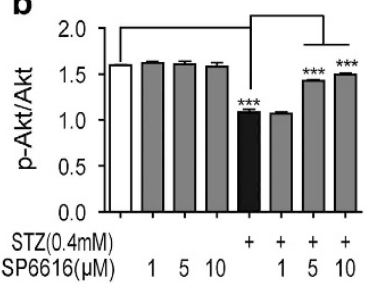

C

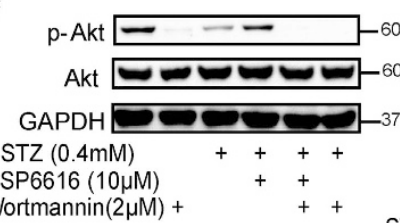

Wortmannin $(2 \mu \mathrm{M})+$
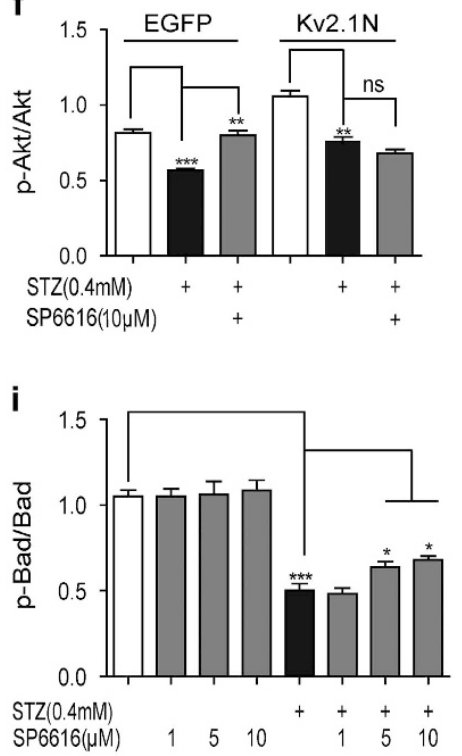

I

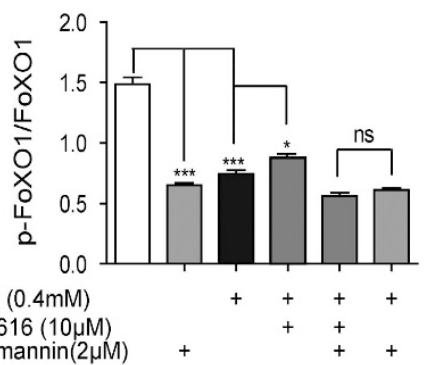

o

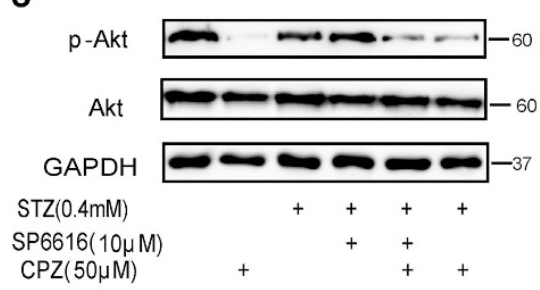

g

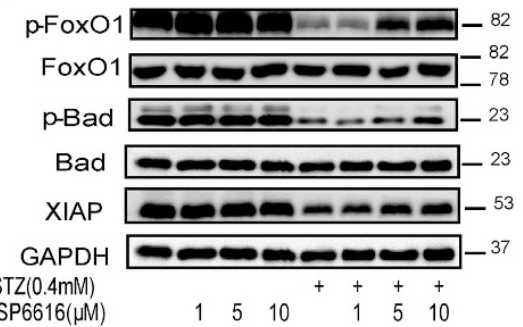

j

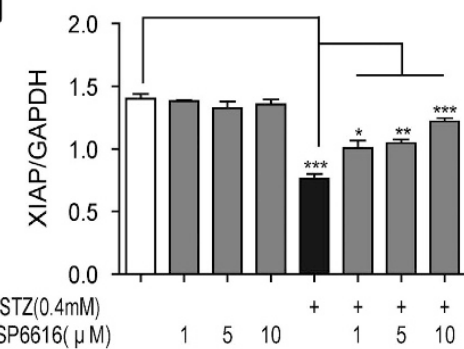

m

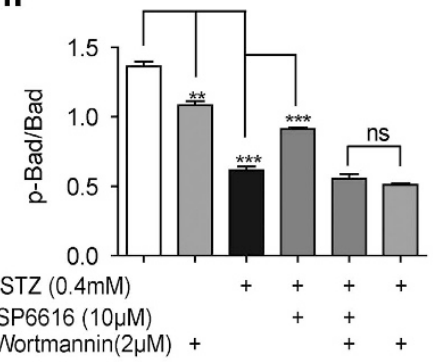

p

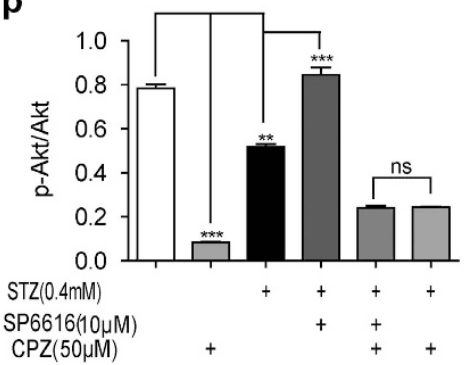


expressing a dominant-negative Kv2 a subunit. ${ }^{52}$ Our results imply that anti-diabetic drug development targeting SP6616 as a lead compound needs further investigation containing pharmacokinetics, pharmaceutics, drug toxicology and even structural modification.
In conclusion, we identified that small molecule SP6616 as a new Kv2.1 inhibitor effectively enhanced insulin secretion and protected $\beta$ cells from apoptosis. It is determined that $\mathrm{PKC} /$ Erk1/2 and CaM/PI3K/Akt pathways are required in parallel for Kv2.1-mediated $\beta$-cell protection (Figure 8e). a

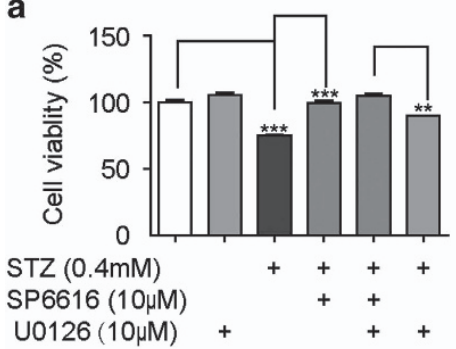

b

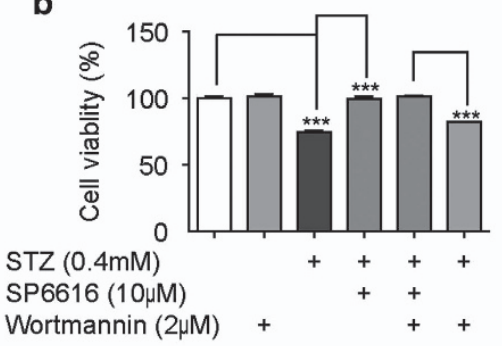

C

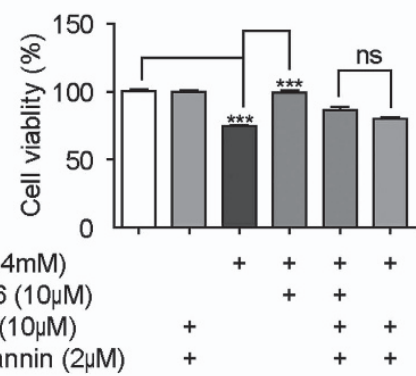

e

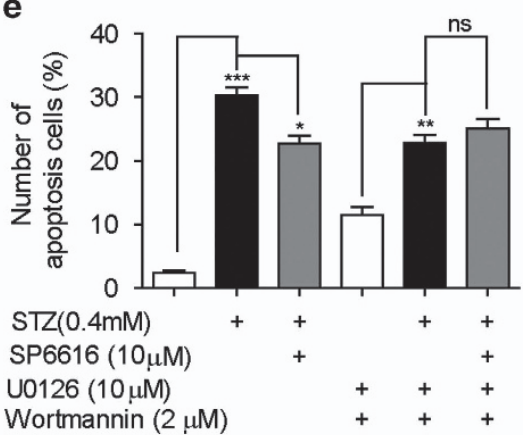

d

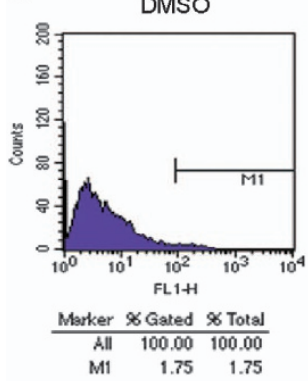

U0126+Wortmannin

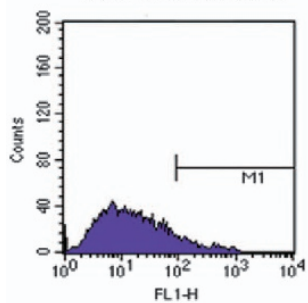

$\frac{\text { Marker \& Gated } \$ \text { Total }}{\text { All } \quad 100.00 \quad 100.00}$

All $\quad 100.00 \quad 100.00$
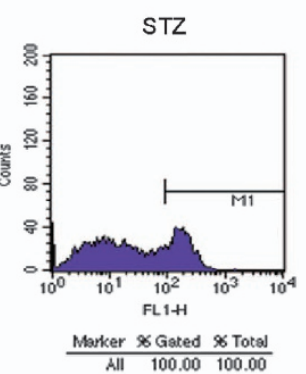

$\begin{array}{rrr}\text { All } & 100.00 & 100.00 \\ \text { M1 } & 32.43 & 32.43\end{array}$
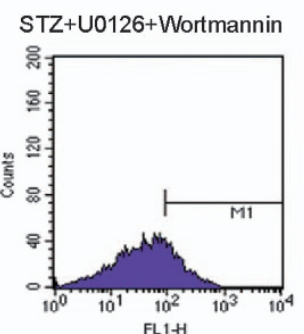

$\frac{\text { Marker } 8 \text { Gated } \$ \text { Total }}{\text { All } 100.00 \quad 100.00}$

M1 $23.38 \quad 23.38$

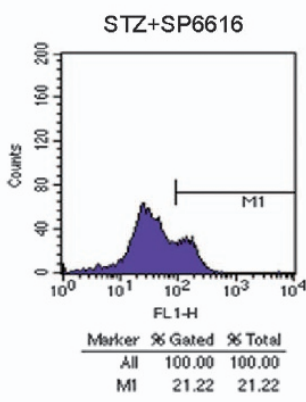

STZ+U0126+Wortmannin+SP6616

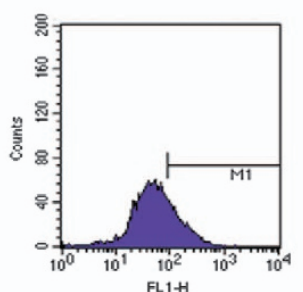

Manker $\$$ Gated $\$$ Total

All $100.00 \quad 100.00$

M1 $24.31 \quad 24.31$

Figure $5 \mathrm{PKC} /$ Erk1/2 and CaM/PI3K/Akt pathways are required in parallel for the protection of SP6616 against $\beta$ cells. (a) INS-832/13 cells were incubated with SP6616 $(10 \mu \mathrm{M})$ and STZ $(0.4 \mathrm{mM})$ in the presence or absence of U0126 $(10 \mu \mathrm{M})$ for $24 \mathrm{~h}$, then MTT assay was conducted. (b) INS-832/13 cells were incubated with SP6616 $(10 \mu \mathrm{M})$ and STZ $(0.4 \mathrm{mM})$ for $20 \mathrm{~h}$ in the presence or absence of wortmmanin $(2 \mu \mathrm{M})$ for another $4 \mathrm{~h}$, and then MTT assay was conducted. (c) INS-832/13 cells were incubated with the corresponding compounds (the same concentrations and incubation time as $\mathbf{a}$ and $\mathbf{b}$ ), and MTT assay was conducted. (d) INS-832/13 cells treated as $\mathbf{c}$ were stained with Annexin V-FITC, and then Annexin V-FITC positive INS-832/13 cells were determined by flow cytometry. (e) The percentage of cell apoptosis was determined by flow cytometry from three independent experiments. All data were obtained from three independent experiments and presented as means \pm S.E.M. $\left({ }^{\star} P<0.05,{ }^{* \star} P<0.01,{ }^{* \star *} P<0.001\right.$; ns, no significance)

Figure $4 \mathrm{CaM} / \mathrm{PI}$ IK/Akt pathway is involved in the SP6616-mediated $\beta$-cell protection. (a) INS-832/13 cells were incubated with SP6616 $(1,5,10 \mu \mathrm{M})$ in the presence or absence of STZ $(0.4 \mathrm{mM})$ for $24 \mathrm{~h}$, and the cell lysate was analyzed by western blot using p-Akt and Akt antibodies. (b) Relative protein levels of p-Akt/Akt in a. (c) INS-832/13 cells were incubated with SP6616 $(10 \mu \mathrm{M})$ and STZ $(0.4 \mathrm{mM})$ for $20 \mathrm{~h}$ in the presence or absence of wortmmanin $(2 \mu \mathrm{M})$ for another $4 \mathrm{~h}$, and then cell lysate was analyzed by western blot using p-Akt and Akt antibodies. (d) Relative protein levels of p-Akt/Akt in c. (e) INS-832/13 cells were transfected with Kv2.1 N or EGFP, and incubated with STZ $(0.4 \mathrm{mM})$ in the presence or absence of SP6616 $(10 \mu \mathrm{M})$, and then the cell lysate was analyzed by western blot using p-Akt and Akt antibodies. (f) Relative protein levels of p-Akt/ Akt in e. (g) INS-832/13 cells were incubated with SP6616 (1, 5, 10 $\mathrm{M}$ ) in the presence or absence of STZ $(0.4 \mathrm{mM})$ for $24 \mathrm{~h}$, and the cell lysate was analyzed by western blot using the corresponding antibodies. (h) Relative protein levels of p-Foxo1/Foxo1 in g. (i) Relative protein levels of p-Bad/Bad in g. (j) Relative protein levels of XIAP/GAPDH in $\mathbf{g}$. (k) INS-832/13 cells were incubated with SP6616 $(10 \mu \mathrm{M})$ and STZ $(0.4 \mathrm{mM})$ for $20 \mathrm{~h}$ in the presence or absence of wortmmanin $(2 \mu \mathrm{M})$ for another $4 \mathrm{~h}$, and then cell lysate was analyzed by western blot using the corresponding antibodies. (I) Relative protein levels of p-Foxo1/Foxo1 in $\mathbf{k}$. (m) Relative protein levels of p-Bad/Bad in $\mathbf{k}$. (n) Relative protein levels of XIAP/GAPDH in k. (o) INS-832/13 cells were pre-incubated with SP6616 $(10 \mu \mathrm{M})$ and STZ $(0.4 \mathrm{mM})$ for $23 \mathrm{~h}$ and then with or without stimulation of CPZ (50 $\mu \mathrm{M})$ for $1 \mathrm{~h}$, finally the cell lysate was analyzed by western blot using p-Akt and Akt antibodies. (p) Relative protein levels of $p$-Akt/Akt in $\mathbf{0}$. All data were obtained from three independent experiments and presented as means \pm S.E.M. $\left({ }^{\star} P<0.05,{ }^{* *} P<0.01,{ }^{* *} P<0.001\right.$; ns, no significance) 


\section{Materials and Methods}

Materials. STZ, ScTX-1, MTT, GFX were purchased from Sigma-Aldrich (St. Louis, MO, USA). U0126 and wortmannin were from Selleck Chemicals (Houston, TX, USA), CPZ from J\&K Scientific (Shanghai, China) and SP6616 from commercial compound library SPECS (Zoetermeer, Netherlands). Antibodies against phospho-Akt(Ser473), Akt, phospho-Erk1/2(T202/Y204), Erk1/2, phosphoFox01(Ser256), Fox01, phospho-Bad(Ser136), Bad, phospho-PKC $\alpha / \beta_{\|}$(T6381641), PKC $\alpha$, XIAP were from Cell Signaling Technology (Danvers, MA, USA), and

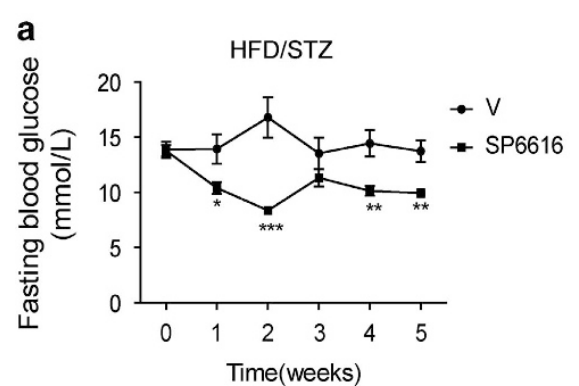

C

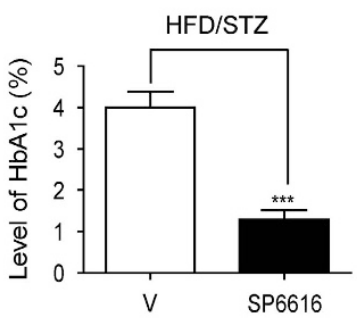

e

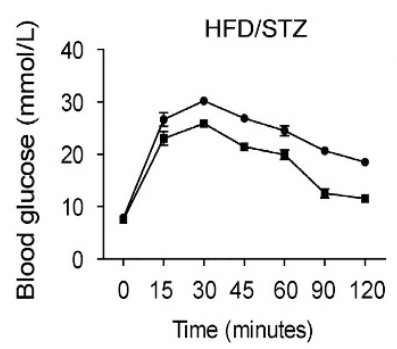

g
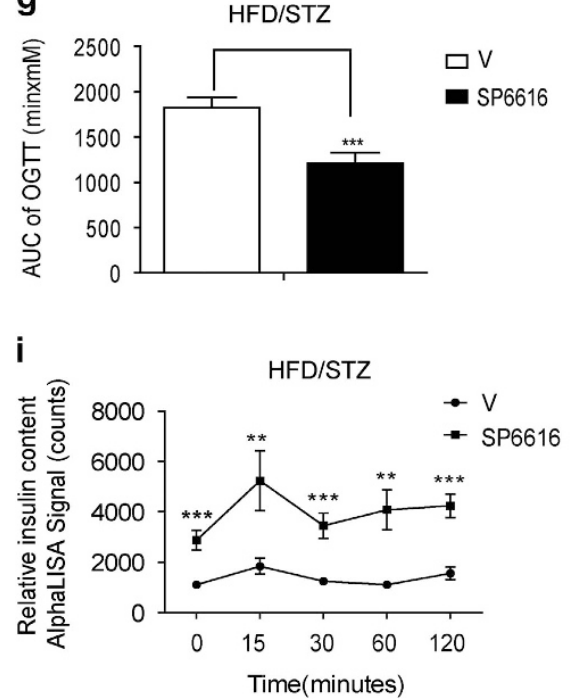

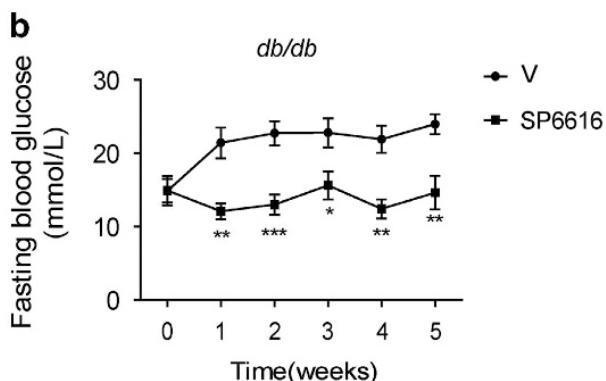

d

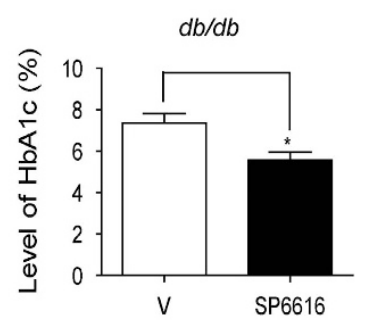

f

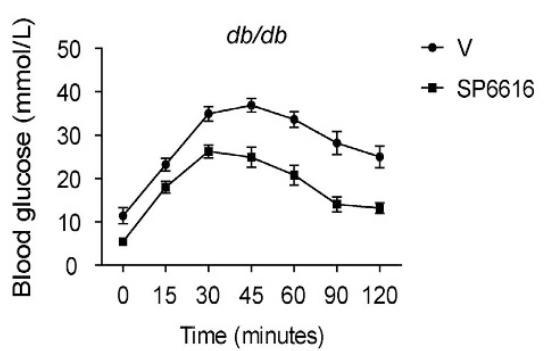

h
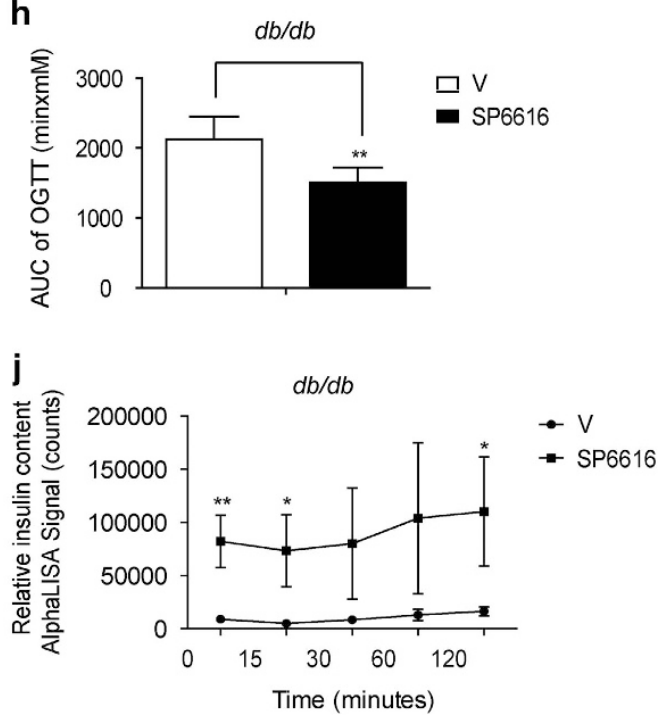

Figure 6 SP6616 effectively ameliorates hyperglycemia in type 2 diabetic model mice. Fasting serum glucose level was detected weekly in (a) HFD/STZ and (b) $d b / d b$ mice with treatment of SP6616 (50 mg/kg/day) ( $n=8)$ (black circles, Vehicle group (V); black squares, SP6616 group (SP6616)). Plasma HbA1c level in (c) HFD/STZ and (d) db/db mice after treatment with SP6616 for 5 weeks was determined. OGTT was performed in (e) HFD/STZ and (f) $d b / d b$ mice with SP6616 treatment $(n=8)$. (g) AUC result of OGTT in e. (h) AUC result of OGTT in f. (i) Serum insulin concentration was determined during OGTT of (e) by AlphaLISA insulin kit. (j) Serum insulin concentration was determined during OGTT of $f$. All data were presented as means \pm S.E.M. $\left({ }^{\star} P<0.05,{ }^{* \star} P<0.01,{ }^{* \star *} P<0.01\right)$ 
a

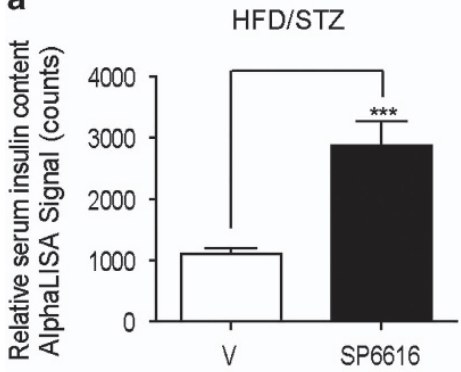

c

HFD/STZ

V

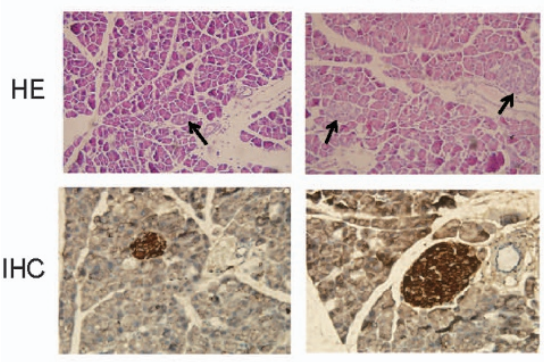

e

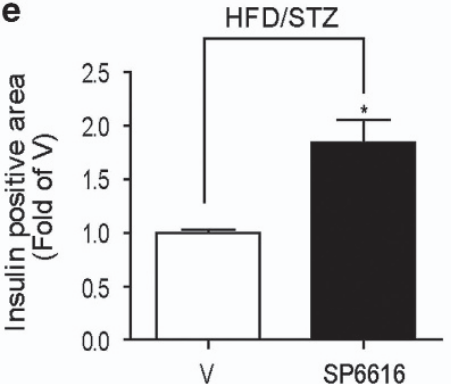

b

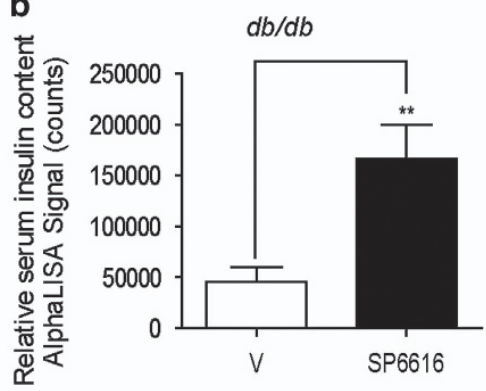

d

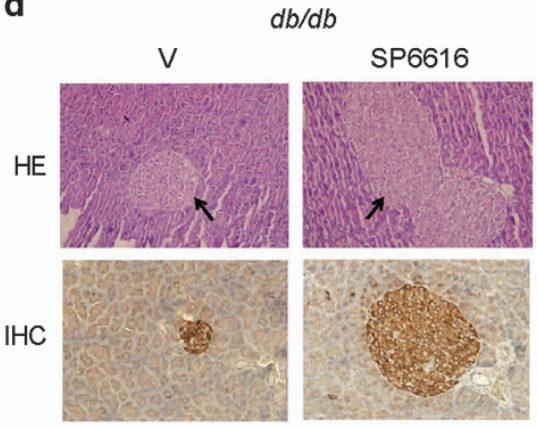

f

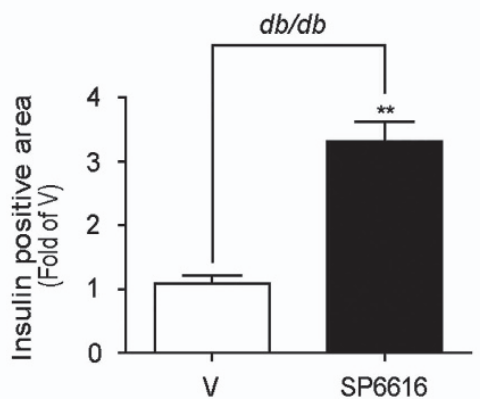

Figure 7 SP6616 promotes insulin secretion and $\beta$-cell mass in type 2 diabetic model mice. Fasting serum insulin level was detected by AlphaLISA insulin kit in (a) HFD/STZ (b) $d b / d b$ mice after the animals were killed ( $n=8$ ). Morphology (HE staining) and insulin immunohistochemistry (IHC) of pancreatic $\beta$ cells in (c) HFD/STZ and (d) $d b / d b$ mice were examined after SP6616 (50 mg/kg/day) treatment for 5 weeks. Arrows pointed to islet and size bar was $100 \mu \mathrm{m}$. (e) Quantification of insulin-positive islets in c. (f) Quantification of insulin-positive islets in d. All data were presented as means \pm S.E.M. $\left({ }^{\star} P<0.05,{ }^{\star \star} P<0.01,{ }^{* \star *} P<0.01\right)$

glyceraldehyde-3-phosphate dehydrogenase (GAPDH) from Kangcheng Biotech (Shanghai, China).

Plasmids. pLV-EYFP-N-Kv2.1 plasmid for lentivirus-mediated stable Kv2.1 overexpression in $\mathrm{CHO}$ cells was constructed from pcDNA3.1a-Kv2.1 as described previously. ${ }^{10}$ Dominant-negative Kv2.1N subunit (Kv2.1N) plasmid was generously gifted by Professor Patrick E MacDonald (University of Toronto, Toronto, Canada).

Cell cultures. INS-832/13 cells (kindly provided by Professor Yong Liu, Institute for Nutritional Sciences, SIBS, Chinese Academy of Sciences) were cultured in RPMI-1640 medium (Invitrogen, Grand Island, NY, USA) supplemented with 10\% fetal bovine serum (FBS; Gibco, Grand Island, NY, USA), $100 \mathrm{U} / \mathrm{ml}$ penicillin and $100 \mathrm{mg} / \mathrm{ml}$ streptomycin, $10 \mathrm{mM}$ HEPES, $2 \mathrm{mM}$ L-glutamine, $1 \mathrm{mM}$ sodium-pyruvate and $0.05 \mathrm{mM} \beta$-mercaptoethanol.

CHO-Kv2.1 cell line was established by infecting the mature lentivirus of Kv2.1 packaged in $293 \mathrm{~T}$ cells and cultured in Dulbecco's modified Eagle's medium (Invitrogen) with $10 \% \mathrm{FBS}, 100 \mathrm{U} / \mathrm{ml}$ penicillin, $100 \mathrm{mg} / \mathrm{ml}$ streptomycin and $0.25 \mu \mathrm{g} / \mathrm{ml}$ puromycin. $\mathrm{CHO}$ cells were cultured under similar conditions except for puromycin selection.

Membrane potential assay. Cellular membrane potential was detected by FLIPR membrane potential assay kit (Molecular Devices, Sunnyvale, CA, USA) according to the instruction manual in $\mathrm{CHO}-\mathrm{Kv} 2.1$ or $\mathrm{CHO}$ cells. Briefly, cells were plated into 96-well microplates and incubated overnight. After treating with compounds and membrane potential dye for $30 \mathrm{~min}$, the plates were loaded into FlexStationll384 (Molecular Devices), followed by injecting $20 \mu \mathrm{M}$ compounds and $100 \mathrm{mM} \mathrm{KCl}$ into the wells to generate the change of cellular membrane potential. The signals in each well were acquired for $120 \mathrm{~s}$ containing $20 \mathrm{~s}$ pre-injection basal reading at excitation wavelength of $530 \mathrm{~nm}$ and emission wavelength of $565 \mathrm{~nm}$. These data were analyzed and shown as the area under the curve (AUC).

Electrophysiological recording assay. The whole-cell patch clamp recordings were performed using cultured $\mathrm{CHO}-\mathrm{Kv} 2.1$ cells at room temperature with Axopatch-200B amplifier (Molecular Devices) as described previously. ${ }^{53}$ The electrodes were pulled from borosilicate glass capillaries (1B150F-4; World Precision Instruments, Sarasota, FL, USA) by using Flaming/Brown type micropipette puller (P-97; Sutter Instrument, Novato, CA, USA). Pipettes had resistances of 3-7 M $\Omega$ when filled with a solution as following composition: $140 \mathrm{mM} \mathrm{KCl}, 2 \mathrm{mM} \mathrm{MgCl}$, $10 \mathrm{mM}$ EGTA, $1 \mathrm{mM} \mathrm{CaCl}$, $10 \mathrm{mM}$ HEPES (pH7.3). Cells were bath perfused with a solution of the following composition: $150 \mathrm{mM} \mathrm{NaCl}, 5 \mathrm{mM} \mathrm{KCl}, 0.5 \mathrm{mM} \mathrm{CaCl}$, $1.2 \mathrm{mM} \mathrm{MgCl}_{2}, 10 \mathrm{mM}$ HEPES (pH7.3). The signals were filtered at $1 \mathrm{kHz}$, digitized using a DigiData 1440 A (Molecular Devices), and analyzed with the software of pClamp 10.2 (Molecular Devices). Whole-cell currents were recorded using the protocol as follows: the holding potential was set at $-80 \mathrm{mV}$, and stepwise depolarized from -80 to $120 \mathrm{mV}$ in $20 \mathrm{mV}$ increments and then repolarized to $-60 \mathrm{mV}$. 
a

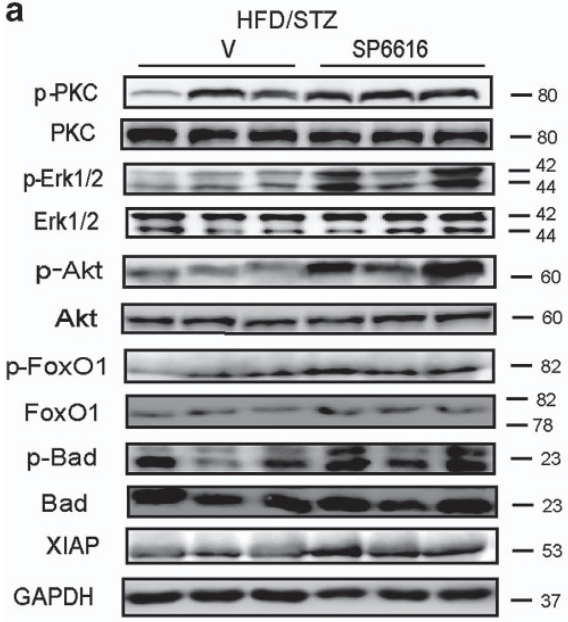

b

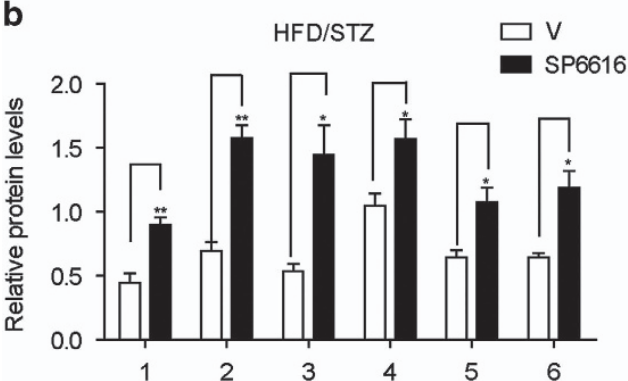

1: p-PKC/GAPDH 2: p-Erk1/2/GAPDH 3: p-Akt/GAPDH 4: p-FoxO1/GAPDH 5: p-Bad/GAPDH 6: XIAP/GAPDH
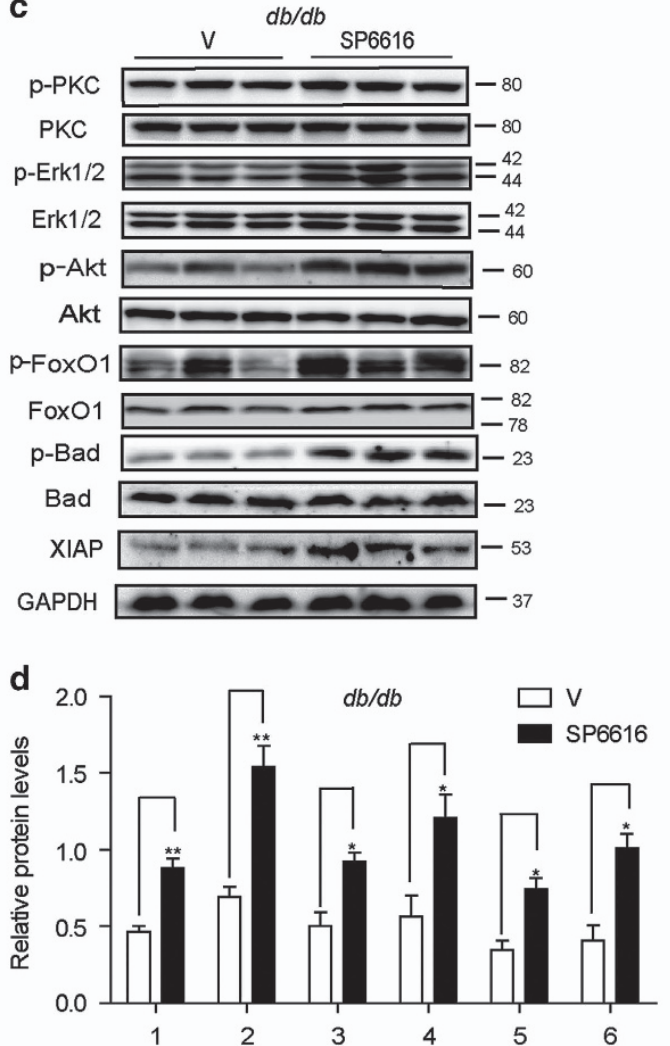

1: p-PKC/GAPDH 2: p-Erk1/2/GAPDH 3: p-Akt/GAPDH 4: p-FoxO1/GAPDH 5: p-Bad/GAPDH 6: XIAP/GAPDH

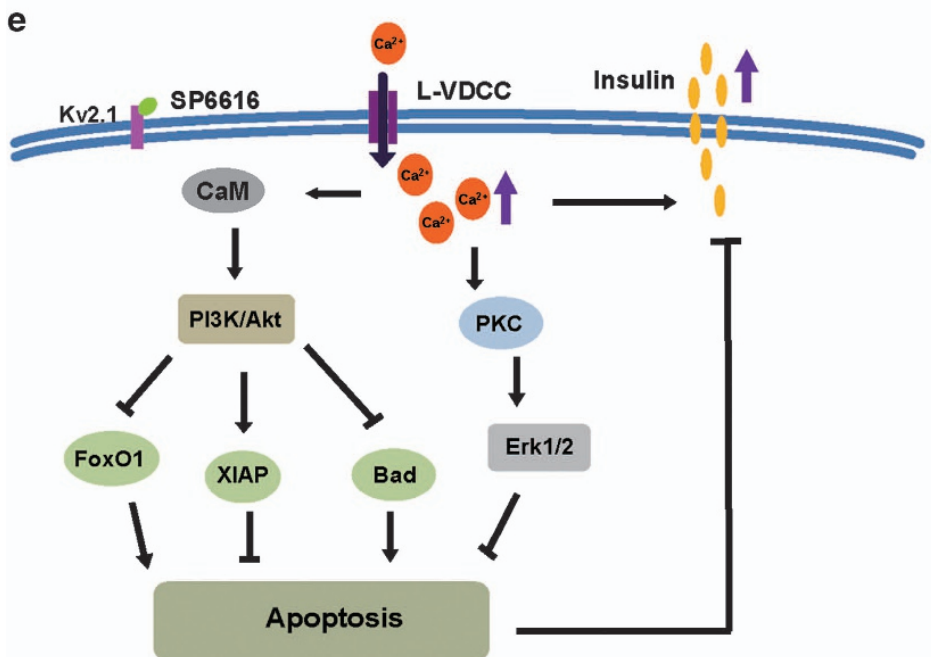

Figure 8 SP6616 regulates Erk1/2 and Akt signaling in vivo. (a) Pancreatic islet tissue extracts from HFD/STZ mice after SP6616 (50 mg/kg/day) treatment for 5 weeks were analyzed by western blot using the corresponding antibodies $(n=3)$. (b) Relative protein levels in a. (c) Pancreatic islet tissue extracts from db/db mice after SP6616 (50 mg/kg/ day) treatment were analyzed by western blot $(n=3)$. (d) Relative protein levels in $\mathbf{c}$. (e) A proposed model interpreting the involvement of PKC/Erk1/2 and CaM/PI3K/Akt signaling pathways in the SP6616-mediated $\beta$-cell protection. All data were presented as means \pm S.E.M. $\left({ }^{\star} P<0.05,{ }^{\star *} P<0.01\right)$

Initially, we made compensation to get rid of pipette resistance during whole-cell patching, and then we made $60-80 \%$ compensation of both series resistance and capacitance of cell bodies to avoid voltage deviations (for the detailed procedures, see also Supplementary Information), especially when the current amplitude is large. For large cells, we further perform the correction offline by recording much of empty control $\mathrm{CHO}$ cells. ${ }^{54}$ Liquid junction potentials were $<2 \mathrm{mV}$, which were calculated using JPCalc software. ${ }^{55}$

GSIS assay. GSIS assay was carried out according to the published approach. ${ }^{13}$ INS-832/13 cells were plated into 24-well plates. After pre-incubated 
with Krebs-Ringer bicarbonate (KRB) buffer $(115 \mathrm{mM} \mathrm{NaCl}, 5 \mathrm{mM} \mathrm{KCl}, 24 \mathrm{mM}$ $\mathrm{NaHCO}_{3}, 2.5 \mathrm{mM} \mathrm{CaCl}_{2}, 1 \mathrm{mM} \mathrm{MgCl}, 10 \mathrm{mM}$ HEPES at pH7.2) supplemented with $0.2 \%$ bovine serum albumin for $2 \mathrm{~h}$, the cells were incubated in KRB buffer containing $16.8 \mathrm{mM}$ glucose and corresponding compounds for another $2 \mathrm{~h}$. Supernatant of the cells was collected to detect insulin content with AlphaLISA insulin kit (PerkinElmer, Fremont, CA, USA). Insulin level was normalized with total protein content.

MTT assay. MTT assay was performed according to previously described. ${ }^{13}$ INS-832/13 cells were plated into 48-well plates and incubated with different concentrations of SP6616 and STZ $(0.4 \mathrm{mM})$ for $24 \mathrm{~h}$ (unless indication, STZ concentration was $0.4 \mathrm{mM}$ and incubation time was fixed at $24 \mathrm{~h}$ throughout this current work).

Flow cytometry assay. INS-832/13 cells were plated into six-well plates and incubated with corresponding compounds as indicated before collecting. Cell apoptosis was measured with Annexin V-FITC apoptosis detection kit (BD Biosciences Company, San Jose, CA, USA) following the manufacturer's protocol. The percentage of cell apoptosis was determined by flow cytometry (BD Biosciences Company).

Intracellular $\mathrm{Ca}^{2+}$ assay. Intracellular $\mathrm{Ca}^{2+}$ measurement was performed in INS-832/13 cells incubated with calcium indicator Fluo-8 AM (2 mM) at $37^{\circ} \mathrm{C}$ for 40-50 min. The relative fluorescence signals were measured for $80 \mathrm{~s}$ with FlexStationll384 at excitation wavelength of $490 \mathrm{~nm}$ and emission wavelength of $514 \mathrm{~nm}$. SP6616 $(1 \mu \mathrm{M}, 5 \mu \mathrm{M}, 10 \mu \mathrm{M})$ in HBSS buffer with $16.8 \mathrm{mM}$ glucose was added to the well after pre-injection basal reading. For evaluation of the SP6616induced intracellular $\mathrm{Ca}^{2+}$ level change in response to STZ, different concentrations of SP6616 in HBSS buffer with $0.4 \mathrm{mM} \mathrm{STZ}$ was added to the well. These data were analyzed and shown as the area under the original curve (AUC).

Western blot and immunohistochemistry assays. Western blot assays were performed as previously described. ${ }^{56} \mathrm{Cell}$ or tissue lysate was separated by SDS-PAGE and transferred to nitrocellulose membrane (GE Healthcare, Madison, WI, USA). After incubation with the corresponding antibodies, membranes were visualized using the West-Dura detection system (Thermo Scientific, Waltham, MA, USA). The signal was collected by ImageQuant LAS 4000 mini (GE Health, USA). Immunohistochemistry assay of pancreas was performed as previously described. ${ }^{10}$

Animal experiments. All animals received humane care and were raised at a relative humidity of $50 \%$ with a 12 -h light-dark cycle at $20-25^{\circ} \mathrm{C}$ and given ad libitum access to water and food. The animal-relevant protocols were approved by the Institutional Animal Care and Use Committees at Shanghai Institute of Materia Medica.

HFD/STZ-induced type 2 diabetic mice were constructed as described. ${ }^{13,57}$ Briefly, 6-week-old C57/BL6 male mice were intraperitoneally injected with STZ (25 mg/kg/ day) continuously for 5 days after feeding with HFD containing $58 \%$ fat for 4 weeks. To select diabetic mice, 6-h fasting plasma glucose was measured in the STZ-injected mice after 3 days. $d b / d b$ male mice (BKS.Cg-Dock $\left.7^{m+/+} L e p r^{d b} / J\right)$ were from Jackson Laboratory (Sacramento, CA, USA). Both diabetic mice were assigned randomly to two groups by glucose level and body weight $(n=8)$. Vehicle $(2 \%$ DMSO and $8 \%$ Tween 80 dissolved in saline) or SP6616 (50 mg/kg/day) was administrated daily by intraperitoneal injection for 5 weeks. Fasting blood glucose level from 6 -h fasted mice was measured weekly. OGTT (1.5 g/kg) was carried out on diabetic mice after fasted overnight at the fourth week. Glucose level was measured from tail blood at 0, 15, 30, $45,60,90$ and $120 \mathrm{~min}$. Meanwhile, the insulin release during OGTT was also detected. Blood sample was obtained from tail veins and serum insulin concentration was determined by AlphaLISA insulin kit (PerkinElmer). At the termination of the study, mice were killed and tissues were analyzed.

Data analysis. Data were shown as means \pm S.E.M. Two-tailed unpaired $t$-test was performed for comparison of two groups and one-way ANOVA analysis for $>2$ groups by GraphPad Prism 5 software (GraphPad Software, La Jolla, CA, USA). Significant differences were shown as ${ }^{*} P<0.05 ;{ }^{* *} P<0.01 ;{ }^{* \star *} P<0.001$.

\section{Conflict of Interest}

The authors declare no conflict of interest.
Acknowledgements. We thank Professor Patrick E MacDonald (Department of Medicine, University of Toronto, Toronto, Canada) for gifting the plasmid of dominant-negative Kv2.1N subunit (Kv2.1N). We thank Professor Yong Liu (Institute for Nutritional Sciences, SIBS, Chinese Academy of Sciences) for kindly providing INS-832/13 cells. This work was supported by the Chinese National Science \& Technology Major Project "Key New Drug Creation and Manufacturing Program" (grant 2014ZX09301-306-003), the National Natural Science Foundation of China (grants 81373461/81473141/81561148011) and the project of Chinese Academy of Sciences Institute of Pharmaceutical Innovation (grants CASIMM0120154035).

1. Xu X, Wang G, Zhou T, Chen L, Chen J, Shen X. Novel approaches to drug discovery for the treatment of type 2 diabetes. Expert Opin Drug Discov 2014; 9: 1047-1058.

2. Prentki M, Nolan CJ. Islet beta cell failure in type 2 diabetes. J Clin Invest 2006; 116 1802-1812.

3. Yang SN, Shi Y, Yang G, Li Y, Yu J, Berggren PO. lonic mechanisms in pancreatic beta cell signaling. Cell Mol Life Sci 2014; 71: 4149-4177.

4. Jacobson DA, Kuznetsov A, Lopez JP, Kash S, Ammala CE, Philipson LH. Kv2.1 ablation alters glucose-induced islet electrical activity, enhancing insulin secretion. Cell Metab 2007; 6: 229-235.

5. MacDonald PE, Wheeler MB. Voltage-dependent $\mathrm{K}(+)$ channels in pancreatic beta cells: role, regulation and potential as therapeutic targets. Diabetologia 2003; 46: 1046-1062.

6. Kim SJ, Widenmaier SB, Choi WS, Nian C, Ao Z, Warnock G et al. Pancreatic beta-cel prosurvival effects of the incretin hormones involve post-translational modification of Kv2.1 delayed rectifier channels. Cell Death Differ 2012; 19: 333-344.

7. Pal S, Hartnett KA, Nerbonne JM, Levitan ES, Aizenman E. Mediation of neuronal apoptosis by Kv2.1-encoded potassium channels. J Neurosci 2003; 23: 4798-4802.

8. Li XN, Herrington J, Petrov A, Ge L, Eiermann G, Xiong Y et al. The role of voltage-gated potassium channels Kv2.1 and Kv2.2 in the regulation of insulin and somatostatin release from pancreatic islets. J Pharmacol Exp Ther 2013; 344: 407-416.

9. MacDonald PE, Sewing S, Wang J, Joseph JW, Smukler SR, Sakellaropoulos G et al. Inhibition of Kv2.1 voltage-dependent $\mathrm{K}+$ channels in pancreatic beta-cells enhances glucose-dependent insulin secretion. J Biol Chem 2002; 277: 44938-44945.

10. Yao XG, Chen F, Li P, Quan L, Chen J, Yu L et al. Natural product vindoline stimulates insulin secretion and efficiently ameliorates glucose homeostasis in diabetic murine models. J Ethnopharmacol 2013; 150: 285-297.

11. Baxter DF, Kirk M, Garcia AF, Raimondi A, Holmqvist MH, Flint KK et al. A novel membrane potential-sensitive fluorescent dye improves cell-based assays for ion channels. J Biomol Screen 2002; 7: 79-85.

12. Braun $M$, Ramracheya $R$, Bengtsson $M$, Zhang $Q$, Karanauskaite $J$, Partridge $C$ et al. Voltage-gated ion channels in human pancreatic beta-cells: electrophysiological characterization and role in insulin secretion. Diabetes 2008; 57: 1618-1628.

13. Yao XG, Xu X, Wang GH, Lei M, Quan LL, Cheng YH et al. BBT improves glucose homeostasis by ameliorating beta-cell dysfunction in type 2 diabetic mice. J Endocrinol 2015; 224: 327-341.

14. MacDonald PE, Ha XF, Wang J, Smukler SR, Sun AM, Gaisano HY et al. Members of the Kv1 and $\mathrm{Kv2}$ voltage-dependent $\mathrm{K}(+)$ channel families regulate insulin secretion. Mol Endocrinol 2001; 15: 1423-1435.

15. Quevedo J, Vianna M, Daroit D, Born AG, Kuyven CR, Roesler R et al. L-type voltagedependent calcium channel blocker nifedipine enhances memory retention when infused into the hippocampus. Neurobiol Learn Mem 1998; 69: 320-325.

16. Jacobson DA, Mendez F, Thompson M, Torres J, Cochet O, Philipson LH. Calcium-activated and voltage-gated potassium channels of the pancreatic islet impart distinct and complementary roles during secretagogue induced electrical responses. J Physiol 2010; 588: 3525-3537.

17. Cross TG, Scheel-Toellner D, Henriquez NV, Deacon E, Salmon M, Lord JM. Serine/ threonine protein kinases and apoptosis. Exp Cell Res 2000; 256: 34-41.

18. Weisfelner ME, Gottlieb AB. The role of apoptosis in human epidermal keratinocytes. $J$ Drugs Dermatol 2003; 2: 385-391.

19. Kolch W, Heidecker G, Kochs G, Hummel R, Vahidi H, Mischak $\mathrm{H}$ et al. Protein kinase $\mathrm{C}$ alpha activates RAF-1 by direct phosphorylation. Nature 1993; 364: 249-252.

20. Buitrago L, Bhavanasi D, Dangelmaier C, Manne BK, Badolia R, Borgognone A et al. Tyrosine phosphorylation on spleen tyrosine kinase (Syk) is differentially regulated in human and murine platelets by protein kinase C isoforms. J Biol Chem 2013; 288: 29160-29169.

21. Wrede CE, Dickson LM, Lingohr MK, Briaud I, Rhodes CJ. Fatty acid and phorbol estermediated interference of mitogenic signaling via novel protein kinase $\mathrm{C}$ isoforms in pancreatic beta-cells (INS-1). J Mol Endocrinol 2003; 30: 271-286.

22. Tanaka Y, Gavrielides MV, Mitsuuchi Y, Fujii T, Kazanietz MG. Protein kinase C promotes apoptosis in LNCaP prostate cancer cells through activation of p38 MAPK and inhibition of the Akt survival pathway. J Biol Chem 2003; 278: 33753-33762.

23. Elghazi L, Rachdi L, Weiss AJ, Cras-Meneur C, Bernal-Mizrachi E. Regulation of beta-cell mass and function by the Akt/protein kinase B signalling pathway. Diabetes Obes Metab 2007; 9: 147-157.

24. Xu J, Zhang QG, Li C, Zhang GY. Subtoxic N-methyl-D-aspartate delayed neuronal death in ischemic brain injury through TrkB receptor- and calmodulin-mediated PI-3K/Akt pathway activation. Hippocampus 2007; 17: 525-537. 
25. Perez-Garcia MJ, Cena V, de Pablo Y, Llovera M, Comella JX, Soler RM. Glial cell linederived neurotrophic factor increases intracellular calcium concentration. Role of calcium/ calmodulin in the activation of the phosphatidylinositol 3-kinase pathway. J Biol Chem 2004; 279: 6132-6142.

26. Trajkovic S, Zhang X, Daunert S, Cai Y. Atomic force microscopy study of the conformational change in immobilized calmodulin. Langmuir 2011; 27: 10793-10799.

27. Frolov RV, Singh S. Celecoxib and ion channels: a story of unexpected discoveries. Eur $J$ Pharmacol 2014; 730: 61-71.

28. Cryer PE, Davis SN, Shamoon H. Hypoglycemia in diabetes. Diabetes Care 2003; 26: 1902-1912.

29. Tamarina NA, Kuznetsov A, Fridlyand LE, Philipson LH. Delayed-rectifier (KV2.1) regulation of pancreatic beta-cell calcium responses to glucose: inhibitor specificity and modeling. Am J Physiol Endocrinol Metab 2005; 289: E578-E585.

30. Shiau YS, Huang PT, Liou HH, Liaw YC, Shiau YY, Lou KL. Structural basis of binding and inhibition of novel tarantula toxins in mammalian voltage-dependent potassium channels. Chem Res Toxicol 2003; 16: 1217-1225.

31. Swartz KJ, MacKinnon R. An inhibitor of the Kv2.1 potassium channel isolated from the venom of a Chilean tarantula. Neuron 1995; 15: 941-949.

32. Escoubas P, Diochot S, Celerier ML, Nakajima T, Lazdunski M. Novel tarantula toxins for subtypes of voltage-dependent potassium channels in the Kv2 and Kv4 subfamilies. Mol Pharmacol 2002; 62: 48-57.

33. Lee CW, Kim S, Roh SH, Endoh H, Kodera Y, Maeda T et al. Solution structure and functional characterization of SGTx1, a modifier of Kv2.1 channel gating. Biochemistry 2004; 43: 890-897.

34. Leung YM, Kang YH, Xia FZ, Sheu L, Gao XD, Xie HL et al. Open form of syntaxin-1A is a more potent inhibitor than wild-type syntaxin-1A of Kv2.1 channels. Biochem J 2005; 387: 195-202.

35. Liu H, Liu J, Liang S, Xiong H. Plasma gelsolin protects HIV-1 gp120-Induced neuronal injury via voltage-gated K channel Kv2.1. Mol Cell Neurosci 2013; 57: 73-82.

36. Chen M, Li J, Zhang F, Liu Z. Isolation and characterization of SsmTX-I, a Specific Kv2.1 blocker from the venom of the centipede Scolopendra Subspinipes Mutilans L. Koch. J Pept Sci 2014; 20: 159-164.

37. Zhang HX, Zhang W, Jin HW, Wang XL. Galantamine blocks cloned Kv2.1, but not Kv 1.5 potassium channels. Brain Res Mol Brain Res 2004; 131: 136-140.

38. Noguchi C, Yang J, Sakamoto K, Maeda R, Takahashi K, Takasugi H et al. Inhibitory effects of isoliquiritigenin and licorice extract on voltage-dependent $\mathrm{K}(+)$ currents in $\mathrm{H} 9 \mathrm{c} 2$ cells. J Pharmacol Sci 2008; 108: 439-445.

39. Zaks-Makhina E, Kim Y, Aizenman E, Levitan ES. Novel neuroprotective K+ channel inhibitor identified by high-throughput screening in yeast. Mol Pharmacol 2004; 65: 214-219.

40. Yuan H, Wang WP, Feng N, Wang L, Wang XL. Donepezil attenuated oxygen-glucose deprivation insult by blocking Kv2.1 potassium channels. Eur J Pharmacol 2011; 657: 76-83.

41. Sayed HH, Shamroukh AH, Rashad AE. Synthesis and biological evaluation of some pyrimidine, pyrimido[2,1-b][1,3]thiazine and thiazolo[3,2-a]pyrimidine derivatives. Acta Pharm 2006; 56: 231-244.

42. Clapham DE. Calcium signaling. Cell 2007; 131: 1047-1058.

43. Chien ST, Shi MD, Lee YC, Te CC, Shih YW. Galangin, a novel dietary flavonoid, attenuates metastatic feature via PKC/ERK signaling pathway in TPA-treated liver cancer HepG2 cells. Cancer Cell Int 2015; 15: 15.

44. Granata R, Settanni F, Biancone L, Trovato L, Nano R, Bertuzzi F et al. Acylated and unacylated ghrelin promote proliferation and inhibit apoptosis of pancreatic beta-cells and human islets: involvement of $3^{\prime}, 5^{\prime}$-cyclic adenosine monophosphate/protein kinase $A$, extracellular signal-regulated kinase 1/2, and phosphatidyl inositol 3-Kinase/Akt signaling. Endocrinology 2007; 148: 512-529.
45. Favaro E, Granata R, Miceli I, Baragli A, Settanni F, Cavallo Perin P et al. The ghrelin gene products and exendin-4 promote survival of human pancreatic islet endothelial cells in hyperglycaemic conditions, through phosphoinositide 3-kinase/Akt, extracellular signalrelated kinase (ERK)1/2 and cAMP/protein kinase A (PKA) signalling pathways. Diabetologia 2012; 55: 1058-1070.

46. Chin D, Means AR. Calmodulin: a prototypical calcium sensor. Trends Cell Biol 2000; 10: 322-328.

47. Shukla S, Rizvi F, Raisuddin S, Kakkar P. FoxO proteins' nuclear retention and BH3-only protein Bim induction evoke mitochondrial dysfunction-mediated apoptosis in berberinetreated HepG2 cells. Free Radic Biol Med 2014; 76: 185-199.

48. Shao S, Nie M, Chen $\mathrm{C}$, Chen $\mathrm{X}$, Zhang M, Yuan $\mathrm{G}$ et al. Protective action of liraglutide in beta cells under lipotoxic stress via PI3K/Akt/FoxO1 pathway. J Cell Biochem 2014; 115 : $1166-1175$.

49. Bing L, Wu J, Zhang J, Chen Y, Hong Z, Zu H. DHT inhibits the Abeta25-35-induced apoptosis by regulation of Seladin-1, survivin, XIAP, bax, and bcl-xl expression through a rapid PI3-K/Akt signaling in C6 glial cell lines. Neurochem Res 2014; 40: 41-48.

50. Altieri DC. Survivin and IAP proteins in cell-death mechanisms. Biochem J 2010; 430: 199-205.

51. Strasser A, Huang DC, Vaux DL. The role of the bcl-2/ced-9 gene family in cancer and general implications of defects in cell death control for tumourigenesis and resistance to chemotherapy. Biochim Biophys Acta 1997; 1333: F151-F178.

52. Xu H, Barry DM, Li H, Brunet S, Guo W, Nerbonne JM. Attenuation of the slow component of delayed rectification, action potential prolongation, and triggered activity in mice expressing a dominant-negative Kv2 alpha subunit. Circ Res 1999; 85: 623-633.

53. Li Y, Gamper N, Hilgemann DW, Shapiro MS. Regulation of Kv7 (KCNQ) K+ channel open probability by phosphatidylinositol 4,5-bisphosphate. J Neurosci 2005; 25: 9825-9835.

54. Li Y, Hu GY. Huperzine A, a nootropic agent, inhibits fast transient potassium current in rat dissociated hippocampal neurons. Neurosci Lett 2002; 324: 25-28.

55. Barry PH. JPCalc, a software package for calculating liquid junction potential corrections in patch-clamp, intracellular, epithelial and bilayer measurements and for correcting junction potential measurements. J Neurosci Methods 1994; 51: 107-116.

56. Tang X, Shen H, Chen J, Wang X, Zhang Y, Chen LL et al. Activating transcription factor 6 protects insulin receptor from ER stress-stimulated desensitization via p42/44 ERK pathway. Acta Pharmacol Sin 2011; 32: 1138-1147.

57. Wu Y, Ouyang JP, Wu K, Wang SS, Wen CY, Xia ZY. Rosiglitazone ameliorates abnormal expression and activity of protein tyrosine phosphatase $1 \mathrm{~B}$ in the skeletal muscle of fat-fed, streptozotocin-treated diabetic rats. Brit J Pharmacol 2005; 146: 234-243.

(1) Cell Death and Disease is an open-access journal published by Nature Publishing Group. This work is licensed under a Creative Commons Attribution 4.0 International License. The images or other third party material in this article are included in the article's Creative Commons license, unless indicated otherwise in the credit line; if the material is not included under the Creative Commons license, users will need to obtain permission from the license holder to reproduce the material. To view a copy of this license, visit http://creativecommons.org/licenses/by/4.0/ 